Copyright (C) The Author(s), 2022. Published by Cambridge University Press for The American Society of International Law. This is an Open Access article, distributed under the terms of the Creative Commons Attribution licence (http://creativecommons. org/licenses/by/4.0/), which permits unrestricted re-use, distribution, and reproduction in any medium, provided the original work is properly cited.

doi:10.1017/ajil.2022.2

\title{
Manufacturing Statelessness
}

\author{
By Neha Jain ${ }^{*}$
}

\section{ABSTRACT}

Having recently emerged from its unenviable status as the runt of international law, the phenomenon of statelessness nonetheless eludes traditional international legal instruments. Confronted with questions of nationality that typically fall within the domain of sovereignty, international and regional human rights bodies struggle to rein in the increasingly creative measures that states adopt to obscure the production and persistence of statelessness. This Article uncovers and dissects the different ways in which states manufacture statelessness not through explicitly discriminatory laws and unequal treatment, but through manipulating ostensibly neutral criteria for nationality. The Article identifies three such criteria that are not traditionally considered "suspect" categories for the grant or denial of nationality: time, territory, and administrative practice. It also suggests doctrinal, policy, and strategic tools for identifying and responding to the types of statelessness that are not a collateral consequence of state failure or incompetence, but the outcome of state intentionality.

\section{INTRODUCTION}

The time is the 1920s, after the "Great War of Freedom." Gerard Gales, an American seaman and the fictional protagonist of B. Traven's sensational novel The Death Ship, is stranded in Antwerp, penniless and paperless. To be paperless is to officially not exist. Unable to prove either citizenship or alien-ness, Gales is churned and spat out by one faceless bureaucracy after another, shunted between prisons, consulates, and police stations as he is repeatedly arrested and deported. Without a seaman's pass or any other form of identification, and with no means of securing legal residence or employment in any state, Gales eventually finds refuge on the only entity that will accept him, no questions asked-the "death ship" Yorikke-an arms smuggling vessel manned by a crew consisting almost entirely of stateless, homeless, or undocumented individuals like Gales, trapped in horrifically brutal slave-like conditions on a living hell ship that is bound for destruction. ${ }^{1}$ Described as an arresting allegory of the "horrible things that can happen to a man in the cockeyed postwar world of Europe . . . a world

\footnotetext{
* Associate professor of law, University of Minnesota Law School, United States; Professor of Public International Law and Co-Director of the Academy of European Law, European University Institute in Italy. For illuminating comments and discussions, I am grateful to Jessica Clarke, Martijn Hesselink, Sarah Nouwen, Maarten Vink, and participants in workshops at Northwestern Pritzker School of Law, European University Institute, O.P. Jindal Global University, Hebrew University, and Edinburgh Law School.

${ }^{1}$ B. Traven, The Death Ship (1934).
} 
gone mad,"2 the narrative is no less applicable to the cockeyed world of today where a reported 3.9 million people are currently stateless. ${ }^{3}$

Unlike the statelessness on the Death Ship, which unfolds against the backdrop of wartime and post-war nationalism and scatters the dispossessed in far flung territories-or even on the no-man's land of the high seas-statelessness today is not merely, or even mostly, a product of state conflict. ${ }^{4}$ Nor does it involve displacement beyond the territory of the state. ${ }^{5}$ And, most importantly, statelessness is not a random act of misfortune that could have just as easily have befallen some other hapless victim. Nevertheless, the long shadow of the post-war discourse on statelessness continues to inform international legal responses to the plight of the stateless. This Article argues that the post-war topography of statelessness has been reshaped in significant ways by statelessness as statecraft. ${ }^{6}$ This terrain calls for sophisticated litigation and policy tools to successfully navigate and challenge statelessness that is not a collateral consequence of state failure or incompetence, but the outcome of state intentionality.

Drawing on a wide range of both familiar and more obscure country-specific cases of statelessness, this Article uncovers and highlights how states deliberately produce statelessness not through explicitly discriminatory laws or unequal treatment, but through tampering with facially impartial criteria for access to citizenship. The Article identifies three such criteria that are not traditionally considered as "suspect" classifications for the grant or denial of political membership: time, territory, and administrative practice. For example, instead of enacting citizenship laws that exclude individuals on the basis of ethnic origin, states achieve the same result by "zero option" rules that award citizenship based on physical presence on the territory of the state on a certain date. Members of marginalized groups who cannot furnish documentary proof of this residence may be excluded from citizenship altogether, or may be subjected to protracted administrative procedures whereby the acquisition of nationality is

\footnotetext{
2 See John Anthony West, Traven's "Death Ship" - Authentic, Hypnotic, and Maybe Alchemical, N.Y. TimeS (Nov. 10, 1985) (quoting Bruce Catton).

${ }^{3}$ Lily Chen, Petra Nahmias \& Sebastian Steinmueller, UNHCR Statistical Reporting on Statelessness, UNHCR Statistics Technical Series 2019/1 (Oct. 2019), at https:/www.unhcr.org/statistics/unhcrstats/5d9e182e7/unhcrstatistical-reporting-statelessness.html.

${ }^{4}$ See, e.g., UNHCR, Ending Statelessness, at https://www.unhcr.org/ending-statelessness.html (identifying various causes for statelessness, including gaps in nationality laws, movement of people outside the country of their birth, state creation and border changes, and citizenship loss or deprivation). As I will argue, these only scratch the surface of the processes through which states manufacture statelessness.

5 See UnhCr, Handbook on Protection of Stateless Persons Under the 1954 Convention Relating to the Status of Stateless Persons, para. 1 (2014) ("Most stateless persons, however, have never crossed borders and find themselves in their 'own country.'”).

${ }^{6}$ There is sophisticated scholarship focusing on specific countries and the ways in which they have deliberately sought to exclude individuals who would be entitled to citizenship status, or indeed may already possess that status and be subsequently stripped of it. This Article draws from this scholarship in the various examples it puts forward to illustrate its thesis. However, most of this scholarship takes the form of in-depth historical or rich ethnographic accounts and it does not typically zoom out from individual case studies to speak to the broader phenomenon of statelessness as manufactured by impartial, neutral criteria that are considered universal prerequisites for citizenship. The bulk of this scholarship is also not written by legal scholars, leaving the international legal dimensions of the phenomena somewhat unexplored. For a notable recent exception, see Michelle Foster \& Jade Roberts, Manufacturing Foreigners: The Law and Politics of Transforming Citizens into Migrants, in RESEARCH HANDBOOK on the Law and Politics of Migration 218 (Catherine Dauvergne ed., 2021) (analyzing the practice of states turning minority populations into foreigners, thus forcibly rendering them stateless, through case studies of the Dominican Republic and India).
} 
contingent on the vagaries of bureaucratic decision making. This Article aims to draw the attention of international legal actors to the ways in which states practice discrimination in disguise to manufacture statelessness under the shadow of the law and to counter efforts at its legitimation.

In doing so, this Article tackles head-on the question posed by the ambitious 2014 \#IBelong Campaign on statelessness by the United Nations High Commissioner for Refugees (UNHCR): what would it take to end statelessness? ${ }^{7}$ The UNHCR has called statelessness an "easily resolvable and preventable issue" 8 and has drawn a ten-point action plan to identify and resolve existing situations of statelessness and prevent future ones from occurring. ${ }^{9}$ However, as this Article shows, these measures are both too little, and too late. Focused as they are on either inadvertent or overtly discriminatory causes of statelessness, and on incentivizing states to adopt formal, technical solutions to statelessness, these policy prescriptions fail to recognize covert state-manufactured statelessness. Even worse, state responses to some of these international recommendations might render effective statelessness all the more invisible, in the process exacerbating rather than eliminating statelessness.

The Article instead capitalizes on the diffused and infrequent challenges that international and regional actors — including courts, human rights bodies, and civil society groups—are beginning to mount in response to the state's production of statelessness to propose a bolder and more sustained international legal response. Much like the shape-shifting nature of the strategies deployed by the state to choreograph statelessness, this new legal roadmap must be sufficiently crafty and agile to match, and even surpass, states' creativity. The Article thus seizes on the potential of indirect discrimination as a doctrinal tool to prevent states from circumventing the prohibition of direct discrimination against categories of individuals who have a sufficiently close connection to the state by targeting ostensibly "neutral" policies and practices that amount to systemic discrimination in the production of statelessness. This tool, however, can only be developed and sharpened if advocates make use of it. Strategic litigation should be part of a broad-based advocacy strategy that brings statelessness claims before different international and regional fora-including those that may not issue binding rulings — with a view to both developing international law norms and empowering domestic human rights actors. The Article also speaks to the policy dimension of combatting statelessness by urging international development and human rights agencies such as the UNHCR to be more targeted in advocating for legal identity documentation and registration as statelessness prevention and reduction measures. Recognizing that these measures can do more harm than good, the Article urges these agencies to scrutinize the legal framework and political conditions within which modern identity management systems are implemented to avoid perpetuating or expanding existing forms of exclusion. Rather than focusing on the utopian prospect championed by the UNHCR to end statelessness in a decade, the Article instead adopts a pragmatic approach that incrementally develops forward-looking ideas, principles, and tools that can be used by actors in plural and diverse national settings to steadily chip away at the circumstances in which statelessness can be produced.

\footnotetext{
7 UNHCR, Global Action Plan to End Statelessness, 2014-2024, at https://www.unhcr.org/ibelong/globalaction-plan-2014-2024.

${ }^{8}$ UN News, Ending Statelessness “A Matter of Political Will," Says UN Refugee Agency Chief(Nov. 11, 2020), at https://news.un.org/en/story/2020/11/1077392.

${ }^{9}$ Global Action Plan to End Statelessness, supra note 7.
} 
This Article proceeds in three Parts. Part I situates the discourse on statelessness within broader debates relating to international law's preoccupation with the stability of the international legal order, the importance of nationality, and the influence of international human rights law on issues concerning citizenship. Part II highlights that in addition to cases of manifest illegality, statelessness is manufactured in more subtle, less visible ways through creative techniques that circumvent international law standards by tampering with ostensibly neutral criteria relevant to nationality. It uncovers three such criteria that masquerade as unbiased markers for citizenship acquisition and the concomitant exclusion from its benefits: time, space, and documents. Part III argues that the halting efforts that international actors are beginning to take to arrest statelessness must be transformed into a bolder legal roadmap with doctrinal, litigation, and policy tools that are equal to the state's creative capacity to manufacture statelessness. A brief conclusion follows.

\section{Statelessness CReep and the LaW}

This Part unpacks the instability of the international legal discourse on statelessness in order to set the stage for accurately diagnosing and responding to international law's blind spots on statelessness. It traces how the emergence of the nation-state as the predominant form of political organization transformed statelessness from an ambivalent status that could be both empowering and disempowering to one of absolute vulnerability. However, international recognition of this vulnerability was overshadowed by the plight of refugee populations during the political upheaval and mass displacements of the mid-twentieth century. As a matter of international legal regulation, statelessness was thus suspended between being viewed as a problem of reconciling state interests through avoiding conflicts in nationality laws, or as subsumed within the more capacious framework of refugee law. ${ }^{10}$ It took continued political turmoil in the form of state dissolutions, state successions, armed conflicts, and boundary disputes, for the international legal community to begin to recognize the stateless as a distinct category in need of international—and not merely domestic-protection.

\section{A. The Regulation of People Without Countries}

The emergence of statelessness in the consciousness of the international community is strongly linked to the rise of protectionism and regulation of human mobility in the wake of World War I. The war signaled an end to the exceptional movement of labor and capital fueled by the nineteenth century spirit of internationalism, technological innovation, and liberal capitalism. ${ }^{11}$ The advent of welfare states in combination with nationalist ideologies resulted in states drawing ever sharper boundaries between those who were their nationals-and thus entitled to the social benefits stemming from political membership-and non-nationals. Central to this boundary drawing was the question of identification, resulting in the proliferation of documentation such as passports and identity cards to serve bureaucratic needs of migration control and internal administration. ${ }^{12}$ As Torpey argues, this

${ }^{10}$ See Mira L. Siegelberg, Statelessness: A Modern History (2020) (for a comprehensive analysis of the historical evolution of the status of statelessness).

${ }^{11} \mathrm{Id}$. at $14-15$.

${ }^{12}$ John Torpey, The Great War and the Birth of the Modern Passport System, in Documenting Individual Identity: The Development of State Practices in the Modern World 256, 269-70 (Jane Caplan \& John Torpey eds., 2001). 
extraordinary capacity to regulate human mobility through documentary practices was not merely evidence of the state's expanding authority, but constitutive of its identity as a state. ${ }^{13}$

The significance of nationality as a form of identification, and what its absence represented, must be seen against this evolving interstate order. The end of World War I saw a rise in the number of claims before domestic courts from individuals seeking to be declared stateless in order to avoid penalties associated with their designation as enemy aliens during the war. While these claims had previously been treated with ambivalence and even suspicion due to concerns of national security, courts now began to accord them greater sympathy, spurring efforts toward the recognition of statelessness as a legally valid category. ${ }^{14}$ The stateless person nonetheless continued to be treated as a "res nullius," 15 or a "caput lupinum" 16 whose presence threatened the stability of the post-war international order. As the numbers of stateless persons grew, the question of whether and how their status could be secured on the international plane gained increasing urgency. ${ }^{17}$ Mass denationalization of Russians labeled as enemies of the Bolshevik Revolution coupled with refugee flows from the collapse of the Hapsburg empire served as a catalyst for the emergence of the League of Nations as a potential forum for securing the rights of the dispossessed. ${ }^{18}$

The League was none too keen to assume this mantle, which threatened to destabilize its carefully constructed boundaries between issues that were within the League's "international" mandate, and those that implicated state sovereignty. It thus pressed for a technical, legal solution to the status of those without nationality, painting the problem as one of conflict of nationality laws that could be overcome by harmonization of the diversity of conditions for naturalization and denaturalization in national legal systems. ${ }^{19}$ The outcome of these efforts was the 1930 Hague Conference for the Codification of International Law, which adopted a Convention on Certain Questions Relating to the Conflict of Nationality Laws $^{20}$ and a Protocol Relating to a Certain Case of Statelessness. ${ }^{21}$

Even though the codification of nationality laws was motivated by the object to "reduce the number of cases of, if not to abolish, statelessness and multiple nationality," 22 the Convention and Protocol were regarded by commentators as having achieved fairly little in this respect. ${ }^{23}$ The provisions on reduction of statelessness were in the nature of "negative" obligations on states to prevent the loss of nationality rather than positive obligations to grant nationality. Moreover, the instruments mainly targeted statelessness at birth rather than subsequent

\footnotetext{
${ }^{13}$ Id. at 270.

${ }^{14}$ SiegelberG, supra note 10 , at 45-46.

15 See Georg Schwarzenberger, International LaW 171 (1949).

${ }^{16}$ Hersch Lauterpacht, An International Bill of the Rights of Man 126 (1945).

${ }^{17}$ See 1 Lassa OpPenheim, International LaW 668 (1955) (stating that, with the loss of the link of nationality, the stateless had no means of claiming protection under international law).

${ }^{18}$ Siegelberg, supra note 10 , at 65-67.

${ }^{19} I d$. at 68-69.

20179 LNTS 89, Apr. 13, 1930.

21 179 LNTS 115, Apr. 12, 1930.

${ }^{22}$ Manley O. Hudson, The First Conference for the Codification of International Law, 24 AJIL 447, 450 (1930).

${ }^{23}$ Id.; Richard W. Flournoy, Nationality Convention, Protocols and Recommendations Adopted by the First Conference on the Codification of International Law, 24 AJIL 467, 481-83 (1930).
} 
loss of nationality. ${ }^{24}$ Aware of these limitations, the Conference sought to convey a sense of urgency to states and to the League to persist in efforts to minimize the problem of statelessness, a call that the League failed to heed. ${ }^{25}$

Enmeshed as they were in concerns relating to the constitution of the nation-state and the political division of authority between the domestic and international legal orders, these international efforts to address the problem of those without nationality viewed the dispossessed though the lens of state interests. ${ }^{26}$ The stateless person was a flotsam who posed a problem of order management and risked exacerbating friction between states. By creating a class of people who were "'gatecrashers' in the backyards of others," statelessness posed challenges for states who were their unwilling recipients and thus prevented from controlling the boundaries of their membership. ${ }^{27}$ Seen from this angle, statelessness was "an unfortunate consequence of public international law's errors, rather than a phenomenon with its own weight." 28 While the inter-war period saw increased international attention to statelessness as a problem in its own right, as the subsequent section shows, the plight of stateless persons came to be overshadowed by the more pressing need to respond to another category of dispossessed persons: refugees.

\section{B. Statelessness as the Stepchild to Refugee Status}

The oft-repeated statement that initially, refugees and stateless persons "walked hand in hand," and that the stateless came to be treated as a subset of the refugee population only after World War II, ${ }^{29}$ is only partially accurate. Indeed, the inter-war period saw several attempts to distinguish between the status and needs of the two categories of dispossessed as exemplified by a 1936 editorial comment in the American Journal of International Law that distinguished between stateless persons as individuals who had "lost the diplomatic protection of their national State without acquiring any other national protection" and refugees who had found asylum in other countries. ${ }^{30}$

These nuances became difficult to sustain in the face of national laws such as those enacted by Nazi Germany stripping Jews of their citizenship rights, and subsequently of their nationality. ${ }^{31}$ By the end of World War II, the growing number and scale of the problem of persons who could no longer claim the protection of any nation gave fresh impetus to international efforts to address their status. In 1948, the Economic and Social Council (ECOSOC) charged

\footnotetext{
${ }^{24}$ Paul Weis, The United Nations Convention on the Reduction of Statelessness, 1961, 11 INT'L \& ComP. L. Q. 1073, 1074 (1962).

${ }^{25} \mathrm{Id}$.

${ }^{26}$ Peter J. Spiro, A New International Law of Citizenship, 105 AJIL 694, 709 (2011).

${ }^{27}$ Matthew J. Gibney, Statelessness and Citizenship in Ethical and Political Perspective, in NaTIONALITY AND Statelessness Under International LaW 44, 49 (Alice Edwards \& Laura van Waas eds., 2014).

${ }^{28}$ Will Hanley, Statelessness: An Invisible Theme in the History of International Law, 25 EUR. J. INT'L L. 321, 322 (2014)

${ }^{29}$ Carol A. Batchelor, Stateless Persons: Some Gaps in International Protection, 7 InT'L J. Refugee L. 232, 239 (1995), citing Guy Goodwin-Gill, The Rights of Refugees and Stateless Persons: Problems of Stateless Persons and the Need for International Measures of Protection, in Human Rights Perspective and Challenges (In 1990 And BEYOND) 378, 389-90 (K. P. Saksena ed., 1994).

${ }^{30}$ Arthur K. Kuhn, International Measures for the Relief of Stateless Persons, 30 AJIL 495, 499 (1936).

31 See Siegelberg, supra note 10, at 152-54. See generally Michelle Foster \& Hélène Lambert, International Refugee LaW and the Protection of Stateless Persons 23 (2019).
} 
the UN secretary-general with "undertak[ing] a study of the existing situation in regard to the protection of stateless persons" and "submit[ting] recommendations to the Council as to the desirability of concluding a further convention on this subject." 32 The Study reinforced the notion that the categories of refugees and stateless persons overlapped in large part, focusing as it did primarily on displaced stateless persons rather than those in situ. ${ }^{33}$ This Study and related Memoranda formed the basis for the deliberations of the Ad Hoc Committee on Statelessness and Related Problems constituted by the ECOSOC. ${ }^{34}$ Though the Ad Hoc Committee opted to distinguish between the two categories of persons by proposing a Draft Convention relating to the Status of Refugees and an attached Protocol Concerning Stateless Persons, only the former was eventually adopted by the United Nations Conference of Plenipotentiaries on the Status of Refugees and Stateless Persons in the form of the Refugee Convention. The Protocol Concerning Stateless Persons was referred for further study. ${ }^{35}$

This background is important for understanding the definition of statelessness that was eventually adopted in the 1954 Convention Relating to the Status of Stateless Persons. According to Article 1 of the Convention, a stateless person is one "who is not considered as a national by any State under the operation of its law." 36 Commentators have been critical of this definition, arguing that what it gains in brevity, it loses in treating nationality as a purely technical problem and limiting its scope to de jure stateless persons, excluding situations where an individual is formally a national of a state but this nationality is not effective. ${ }^{37}$ As the drafting history of the Convention makes clear, however, this was not a question of oversight, but a deliberate attempt to avoid overlaps between the 1951 Refugee Convention and the 1954 Statelessness Convention. ${ }^{38}$ The emphasis on de jure statelessness, and the distinction between de jure statelessness and refugees, was retained in the 1961 Convention on the Reduction of Statelessness. The 1961 Convention, initially motivated by the objective of eliminating statelessness, instead dialed this back to the more modest aim of reducing the number of stateless at birth, later in life, and in the course of state succession. ${ }^{39}$

Notwithstanding this cautious and pragmatic approach, the Statelessness Conventions were slow to gain traction, struggling to attract signatories and largely ignored in academic scholarship for the first four decades of their existence, earning them the moniker of "orphan conventions." 40 One of the reasons for this international obscurity was the ambiguity surrounding which agency, if any, was responsible for their promotion and enforcement. ${ }^{41}$ And even though the 1974 Resolution of the General Assembly designated the UNHCR as

${ }^{32}$ UN Economic and Social Council (UNESC), Res. 116 D (VI), UN Doc. E/777 (Mar. 1-2, 1948).

${ }^{33}$ UN Ad Hoc Committee on Refugees and Stateless Persons, A Study of Statelessness, at 4, 10, UN Doc. E/1112 (1949); Foster AND LAMBERT, supra note 31, at 29.

${ }^{34}$ UNESC, Res. 248(IX) (Aug. 6, 1949).

${ }^{35}$ Foster \& LAMBERT, supra note 31, at 36-39.

${ }^{36}$ Convention Relating to the Status of Stateless Persons, Art. 1, Sept. 28, 1954, 360 UNTS 117 (hereinafter 1954 Stateless Convention).

${ }^{37}$ Batchelor, supra note 29, at 232.

${ }^{38} I d$. at $247-48$.

${ }^{39}$ Convention on the Reduction of Statelessness, Art. 1, Aug. 30, 1961, 989 UNTS 175.

40 See Laura van Waas, The UN Statelessness Conventions, in Nationality and Statelessness Under INTERNATIONAL LAW, supra note 27 , at 78.

${ }^{41}$ See Batchelor, supra note 29, at 246-49. 
the agency to which individuals who claimed the protection of the 1961 Convention could apply for assistance, the UNHCR did little to pursue this mandate until the 1990s. ${ }^{42}$

Thus, beginning in the mid-twentieth century, the issue of statelessness came to be consigned to obscurity and was addressed only as an afterthought to the more urgent problem of refugees. This posture has only recently changed, in large part due to the UNHCR's expanded mandate to actively promote accession to the Statelessness Conventions and provide technical assistance to states in drafting and implementing nationality legislation. ${ }^{43}$ The UNHCR has achieved considerable success in its advocacy efforts for the former goal, registering a steady uptick in state accessions to the Conventions. ${ }^{44}$ In addition, it has made important headway in providing technical guidance and advice to states on statelessness by developing guidance on important doctrinal issues, including the definition of stateless persons, stateless determination procedures, the status of stateless persons in the domestic system, and prevention of child statelessness. ${ }^{45}$ It has also worked with a variety of actors on standard setting on nationality issues, played a seminal role in collecting data on and raising awareness of the problems faced by stateless persons, helped states to develop and reform their nationality legislation, and sought to promote birth registration and acquisition of identity documentations. ${ }^{46}$

Even though the UNHCR's recent work demonstrates an awareness of the limitations of a framework oriented to formal, technical solutions for addressing statelessness, it nonetheless exhibits a reluctance to test the boundaries of sovereignty over nationality issues. Thus, for instance, while the 2014 UNHCR Handbook on Protection of Stateless Persons recognizes that statelessness does not only occur in the context of migration but also in situ, it treats the latter as "often the result of problems in the framing and implementation of nationality laws." ${ }^{7}$ Similarly, in elaborating on the meaning of when an individual is "not considered as a national by any State under the operation of its law" for the purposes of Article 1 of the 1954 Convention, the Handbook endorses an understanding of de facto statelessness as referring to individuals outside the country of their nationality who cannot avail themselves of its diplomatic protection notwithstanding that "some participants [in the UNHRC's 2010 expert consultation] were of the view that a person's nationality could be ineffective inside as well as outside of his or her country of nationality." 48 Moreover, as this Article goes on to discuss in Part III, some of the UNHCR's proposed actions to eliminate statelessness,

${ }^{42}$ GA Res. 3274(XXIX) (Dec. 10, 1974); GA Res. $31 / 36$ (Nov. 30, 1976). See van Waas, supra note 40, at 78.

${ }^{43}$ GA Res. 50/152 (Feb. 9, 1996).

${ }^{44}$ See the status at https://treaties.un.org/pages/Home.aspx?clang=_en. As of early 2021, the 1954 Convention has ninety-five parties and twenty-three signatories, whereas the 1961 Convention has seventy-six parties and five signatories.

${ }^{45}$ UNHCR, Guidelines on Statelessness No. 1: The Definition of "Stateless Person" in Article 1(1) of the 1954 Convention Relating to the Status of Stateless Persons, HCR/GS/12/01 (Feb. 20, 2012); UNHCR, Guidelines on Statelessness No. 2: Procedures for Determining Whether an Individual Is a Stateless Person, HCR/GS/12/02 (Apr. 5, 2012); UNHCR, Guidelines on Statelessness No. 3: The Status of Stateless Persons at the National Level, HCR/GS/12/03 (July 17, 2012); UNHCR, Guidelines on Statelessness No. 4: Ensuring Every Child's Right to Acquire a Nationality Through Articles 1-4 of the 1961 Convention on the Reduction of Statelessness, HCR/GS/12/04 (Dec. 21, 2012).

${ }^{46}$ See Mark Manly, UNHCR's Mandate and Activities to Address Statelessness, in NATIONALITY AND STATELESSNESS UNDER INTERNATIONAL LAW, supra note 27, at 88, 97-113.

${ }^{47}$ UNHCR HANDBOOK, supra note 5, para. 1.

${ }^{48} I d$., para. 7, n. 4. 
such as identity registration and documentation drives, may unwittingly exacerbate rather than reduce the incidence of statelessness.

\section{The Human Rights Turn in Statelessness}

While state sovereignty over nationality matters continues to pose a challenge for the international regulation of statelessness, in the past few decades, two developments in international law jurisprudence and scholarship have made incursions into this sovereign space: the first seeks to close the gap between rights accorded to nationals and non-nationals while the second emphasizes the limits set by international law to state control over nationality.

The distinction between the treatment of nationals and non-nationals when it comes to human rights has been questioned by scholars who proclaim the universality of human rights. Decoupling the possession of rights from citizenship status, they argue that one's status as a human being is the only requirement for entitlement to human rights, even though the implementation of these rights requires governmental action at the national level. ${ }^{49}$ This view finds some recognition in both international human rights instruments as well as the Statelessness Conventions, which minimize the importance of nationality. ${ }^{50}$ While these provisions go some way in addressing the rights deprivations experienced by stateless persons, they are nonetheless not a substitute for the right to nationality.

The second, more ambitious, development in international law is the shift from conceiving of nationality in terms of state capacity to control the boundaries of its membership to an individual's right to citizenship. ${ }^{51}$ This reconceptualization, which Peter J. Spiro labels the "new international law of citizenship," is the result of the convergence of legal trends seen across a range of treaty instruments, international tribunals, international and regional organizations, and state practice. In the context of statelessness, the most significant developments relate to greater scrutiny and, in some cases, overruling, of state measures relating to legal and administrative restrictions on acquisition of nationality, in particular in situations of state succession, and the prohibition of discrimination in access to citizenship. ${ }^{52}$ There is, however, significant diversity on how the different human rights "regimes" choose to frame the issue of statelessness, which is typically contingent on the narrow focus of the regime. And the regimes themselves remain underdeveloped in important respects and leave much to state discretion.

For example, while there have been significant developments in the international law of state succession that seek to avoid statelessness, there is lack of clarity on the exact content of state obligations in this respect, leading one commentator to remark "[i]f the law of state succession in respect of treaties is the most well-developed area of the law of state succession, the nationality of persons is a strong contender for being the least well-developed." 53

\footnotetext{
49 See David Weissbrodt \& Clay Collins, The Human Rights of Stateless Persons, 28 Hum. RTs. Q. 245, 248-49 (2006).

${ }^{50}$ Id. at 249-50. For example, Article 4 of the 1954 Stateless Convention enjoins states to grant lawfully resident stateless persons rights that are equivalent to nationals in certain respects such as religion, access to elementary education, and public relief.

51 See Spiro, supra note 26, at 695-96.

52 See id. at 721-22.

53 James G. Devaney, What Happens Next? The Law of State Succession, 1, 19 (GCILS Working Paper, No. 6, Nov. 2020).
} 
There is no multilateral treaty or clear customary international law imposing binding obligations on states with respect to conferral of nationality and avoidance of statelessness in the context of state succession. ${ }^{54}$ However, there have been important regional initiatives to codify and develop the international law on this issue, in particular in Europe, in the form of the 1997 European Convention on Nationality and the 2006 Council of Europe Convention on the Avoidance of Statelessness in relation to State Succession. ${ }^{55}$ These instruments nonetheless give states ample discretion as to the procedure for granting nationality. ${ }^{56}$

A parallel international effort is the International Law Commission's (ILC) 1999 Articles on Nationality of Natural Persons in relation to the Succession of States. ${ }^{57}$ The Articles provide progressive principles for the attribution of nationality on various grounds, whereby, among others, those with "habitual residence" in the state affected by state succession acquire the nationality of the successor state. ${ }^{58}$ However, the Articles ultimately refrain from imposing concrete obligations on states, only urging states to take "all reasonable measures" to avoid persons becoming stateless as a result of state succession. ${ }^{59}$ And despite this cautious approach, the Articles have not led to the conclusion of a binding multilateral instrument.

Another area in which the international law framework governing statelessness is progressively gathering pace, but nonetheless contains some ambiguity and loopholes, relates to non-discrimination in the context of nationality acquisition. It is worth noting that-notwithstanding discrimination having been recognized as both a cause and a consequence of statelessness - unlike gender discrimination and statelessness of children, statelessness on account of racial discrimination is not at the forefront of international initiatives such as the UNHCR's \#IBelong campaign aiming to eliminate statelessness by $2024 .{ }^{60}$ This is in part due to the wording of the 1966 International Convention on the Elimination of All Forms of Racial Discrimination. ${ }^{61}$ Though Article 5(iii)(d) of the Convention explicitly prohibits discrimination with respect to a right to nationality, its scope is limited by operation of Article 1(2), which excludes from the Convention's ambit distinctions between nationals and non-nationals and Article 1(3), which affirms that "[n]othing in this Convention may be interpreted as affecting in any way the legal provisions of States Parties concerning nationality,

\footnotetext{
54 See Andreas Zimmermann, State Succession and the Nationality of Natural Persons - Facts and Possible Codification, in LA SUCCESSION D'ÉTATS: LA CODIFICATION À L'ÉPROUVE DES FACTS/STATE SuCCESSION: Codifications Tested Against the Facts 612, 659-61 (Pierre Michel Eisemann \& Martti Koskenniemi eds., 2000) (surveying state practice and evidence of customary international law on the question of conferral of nationality and obligation to avoid statelessness in the context of state succession).

55 See Jeffrey L. Blackman, State Successions and Statelessness: The Emerging Right to an Effective Nationality Under International Law, 19 MiCH. J. INT'L L. 1141, 1164-94 (1998) (for an excellent overview of these developments).

${ }^{56}$ European Convention on Nationality, Art. 18(2), Nov. 6, 1997, 37 ILM 44; Council of Europe Convention on the Avoidance of Statelessness in relation to State Succession, Arts. 5-6, May 19, 2006, ETS No. 200, Explanatory Report, para. 19.

57 International Law Commission, Draft Articles on Nationality of Natural Persons in Relation to the Succession of States, UN Doc. A/54/10 (Apr. 3, 1999).

${ }^{58}$ Ineta Ziemele, State Succession and Issues of Nationality and Statelessness, in NATIONALITY AND STATELESSNESS UNDER INTERNATIONAL LAW, supra note 27, at 217, 229.

59 ILC Draft Articles, supra note 57, Art. 4.

${ }^{60}$ Michelle Foster \& Timnah Rachel Baker, Racial Discrimination in Nationality Laws: A Blindspot of International Law?, 11 Colum. J. RaCE \& L. 83, 90-91 (2021).

${ }^{61}$ International Convention on the Elimination of All Forms of Racial Discrimination, Mar. 7, 1966, 660 UNTS 195.
} 
citizenship or naturalization, provided that such provisions do not discriminate against any particular nationality." The net effect is that while states may not discriminate internally between citizens on the basis of race, they are nonetheless not constrained from having racial criteria for acquisition of nationality in the first place. ${ }^{62}$ Nor are they prevented from enacting laws that target multiple nationalities rather than one particular nationality. ${ }^{63}$

The monitoring body for the Convention - the Committee on the Elimination of Racial Discrimination-has also historically been reluctant to interfere with naturalization laws. ${ }^{64}$ In more recent years, however, it has adopted a more aggressive stance as exemplified in its 2004 General Recommendation Thirty, which enjoins states to ensure that "particular groups of non-citizens are not discriminated against with regard to access to citizenship or naturalization, and to pay due attention to possible barriers to naturalization that may exist for long-term or permanent residents." States are reminded that "deprivation of citizenship on the basis of race, colour, descent, or national or ethnic origin is a breach of States parties' obligations to ensure non-discriminatory enjoyment of the right to nationality." 65

However, notwithstanding this statement of principles, in practice, the Committee has not always been consistent in its willingness to call out and condemn discriminatory laws on nationality. ${ }^{66}$ Surveying the Committee's observations on individual country reports over a period of thirty years, Foster and Baker conclude that, with few exceptions, the Committee generally uses "soft" language to evaluate discriminatory laws when it comes to state denial of nationality, reserving the stronger language of breach for nationality deprivations and withdrawals. ${ }^{67}$ There is also no overarching analysis of the relationship between Article 5(iii)(d) and Article 1(3), leaving it open to states to rely on the latter as excluding the Convention's application to acquisition of nationality. ${ }^{68}$

In contrast to the relatively weak international legal framework, some of the most significant legal efforts in cabining state discretion over nationality—and in the process, addressing statelessness as a matter of international concern — can be seen at the regional level. The InterAmerican Court of Human of Rights (IACtHR) and the African Court on Human and Peoples' Rights (AfCHPR) have elected to take a progressively bold stance in this respect, with important pronouncements of general international law principles governing state obligations in respect of statelessness. ${ }^{69}$ These judgments, however, are highly fact-specific and

62 See Spiro, supra note 26, at 716.

${ }^{63}$ Foster \& Baker, supra note 60, at 87.

${ }^{64}$ See Drew Mahalic \& Joan Gambee Mahalic, The Limitation Provisions of the International Convention on the Elimination of All Forms of Racial Discrimination, 9 Hum. RTs. Q. 74, 79, 82 (1987).

${ }^{65}$ Comm. on Elimination Racial Discrimination, General Recommendation Thirty, on Discrimination Against Non-citizens, paras. 13-14, UN Doc. HRI/GEN/1/Rev.7/Add.1 (May 4, 2005). See also PATrICK Thornberry, The International Convention on the Elimination of All Forms of Racial Discrimination: A COMMENTARY 146 (2016).

${ }^{66}$ Foster \& Baker, supra note 60, at 116.

${ }^{67}$ Id. at $118-123$.

${ }^{68} \mathrm{Id}$. at $124-26$.

${ }^{69}$ See, e.g., The Girls Yean v. Dominican Republic, Preliminary Objections, Merits, Reparations and Costs, Judgment, Inter-Am. Ct. H.R. (ser. C) No. 130 (Sept. 8, 2005); Expelled Dominicans and Haitians v. Dominican Republic, Preliminary Objections, Merits, Reparations and Costs, Judgment, Inter-Am. Ct. H.R. (ser. C) No. 282 (Aug. 28, 2014); Anudo v. Tanzania, Decision, African Court on Human and Peoples' Rights [2108] AFCHPR 5 (Mar. 22, 2018); Penessis v. Tanzania, Decision, African Court on Human and Peoples' Rights [2109] AFCHPR 8 (Nov. 28, 2019). 
primarily focus on state laws and practices relating to deprivation of nationality rather than laws that limit the acquisition of nationality in the first place. Further, as the Article discusses in Part II, these examples of successful supranational litigation represent only a fraction of the strategies that states use to manufacture statelessness in the shadow of the law. Nonetheless, as Part II will show, this emerging regional jurisprudence and other forms of international legal mobilization provides a useful lens for analyzing the ways in which supranational and international institutions - both formal and informal-are beginning to challenge state discretion over questions of nationality and the statelessness that can follow in its wake.

International law's uneasy relationship with and response to the notion of statelessness sits at the confluence of shifting conceptions of state sovereignty, political membership, and the boundaries between the international and domestic legal orders. Wary of trespassing into the sovereign space, international laws, institutions, and actors have variously sought to frame statelessness as a technical, legal problem that can be addressed through avoiding conflicts in nationality laws, as the handmaiden to refugee law, or as a highly fact-specific evaluation that is directed toward preventing loss of nationality, once acquired, rather than dictating who gets to be a national in the first place. The next Part shows this framework is at best only partially capable of, and at worst counterproductive for, resolving cases of statelessness that are not a result of incompetence, oversight, or error, but flow from the intentional exercise of state power.

\section{Strategic Statelessness}

The increasingly emboldened stance that international and regional bodies are willing to take to circumscribe states' ability to set the terms of their political membership is largely premised on the belief that statelessness is a product of manifest illegality. To be sure, there are certainly instances, both in the distant past, and also more recently, where states have enacted nationality laws that are blatantly discriminatory or involve mass denationalization. These include well-known cases such as the disenfranchisement and effective loss of nationality of German Jews during the Nazi era to less familiar situations that are closer in time, such as the Sierra Leonean and Liberian nationality laws that restrict citizenship by birth or descent to particular racial groups. ${ }^{70}$ This overt racial discrimination can result in statelessness for those who do not have access to another nationality. ${ }^{71}$

Additionally, a substantial number of countries retain nationality laws that explicitly discriminate on grounds of gender, for example, by preventing women from passing on their nationality to their children. A child who is unable to acquire the nationality of the other parent risks being rendered stateless. ${ }^{72}$ Children of same-sex couples may likewise find themselves at risk of statelessness due to discriminatory laws and practices concerning the recognition of LGBTIQ+ partnerships and legal parentage rights. ${ }^{73}$ In the European context, for

${ }^{70}$ Bronwen Manby, Citizenship in Africa: The Law of Belonging 193 (2018).

${ }^{71}$ Bronwen Manby, Nationality, Migration and Statelessness in West Africa: A Study for UnHCR and IOM 21 (2015), available at https://www.refworld.org/docid/55b886154.html.

${ }^{72}$ See UNHCR, Background Note on Gender Equality, Nationality Laws and Statelessness 2018 (Mar. 8, 2018), available at https://www.refworld.org/docid/5aa10fd94.html.

${ }^{73}$ See generally Thomas McGee, "Rainbow Statelessness"-Between Sexual Citizenship and Legal Theory: Exploring the Statelessness-LGBTQ+ Nexus, 2 Statelessness \& Citizenship Rev. 64, 80-84 (2020). 
example, advocates have highlighted the problems in civil registration and recognition of legal parenthood in the country of nationality of one or both parents in a same-sex couple, leading to difficulties in acquisition of identity documents and nationality by the child, an issue that is the subject of recent litigation before the Court of Justice of the European Union. ${ }^{74}$

Such transparently discriminatory laws are, however, relatively uncommon and represent one extreme of the spectrum of measures through which states may produce statelessness. Statelessness may also be manufactured in more subtle, less visible ways-increasingly, states rely on more creative techniques to circumvent international law standards, including norms on non-discrimination, by tampering with "neutral" criteria that are relevant to nationality and its absence. This Part uncovers three such criteria that masquerade as unbiased markers for citizenship acquisition and the concomitant exclusion from its benefits: time, space, and documents. Drawing on concrete country-specific examples, it illustrates how statelessness as statecraft involves the use and misuse of legal fictions that exploit the disjunction between the physical or factual reality of these elements, their subjective experience, and their legal interpretation.

It is worth stressing that these illustrative cases, which encompass familiar as well as more obscure situations of statelessness, are intended to highlight the ubiquity of the phenomenon across different regions of the world and do not in any way exhaust the universe of state manufactured statelessness. ${ }^{75}$ Indeed, as various international actors as well as the scholarly literature on statelessness note, the UNHCR's statistical count of 3.9 million stateless individuals around the world is likely to be a vast underestimate given that many statelessness people live in the shadows and most states do not have designated statelessness determination procedures. ${ }^{76} \mathrm{It}$ is also for this reason that I include cases of both de jure and de facto statelessness: the shape-shifting character of the techniques that are used to produce statelessness means that there is often a deliberate blurring of the different forms of statelessness in state practice that make it all the more difficult for domestic as well as international institutions, processes, and actors to respond to statelessness as statecraft. States may also toggle between, or simultaneously adopt, different strategies to choreograph and sustain statelessness.

${ }^{74}$ See V.M.A. v. Stolichna Obsthina, Rayon "Pancharevo," Case No. C-490/20, Grand Chamber Judgment (Dec. 14, 2021); Patricia Cabral, Protecting the Right to a Nationality for Children of Same-Sex Couples in the EU-A Key Issue Before the CJEU in V.M.A. v. Stolichna Obsthina (C-490/20), Eur. NeTwOrk STATELESSNESS Blog (Feb. 3, 2021), at https://www.statelessness.eu/updates/blog/protecting-right-nationality-children-same-sex-coupleseu-key-issue-cjeu-vma-v.

${ }^{75}$ For instance, while the situation of the Palestinians has been described as one of the "most widely known situations of statelessness in the world," the Article does not use this as a case study since it cannot easily be separated from the larger question of Palestinian statehood, which is beyond the scope of the Article. The situation is equally complex from the point of view of international regulation, where the UN Reliefs and Works Agency (UNRWA) established with a mandate to assist "Palestinian Refugees" may also include stateless Palestinians in certain cases. For a detailed analysis, see Institute on Statelessness and InClusion, The World's Stateless 127-132 (2014). Similarly, the Article does not address issues of statelessness that are inextricably linked to the contested international legal status of the putative country of nationality, as is the case for the UN-listed non-self-governing territory of Western Sahara. As Manby notes, the absence of UN recognition of Morocco as the administering power coupled with the limited international recognition of the Sahrawi Arab Democratic Republic as an independent state has resulted in a "nationality vacuum" for the Sahrawis. Nevertheless, some states consider persons of Sahrawi origin who cannot be attributed with Moroccan nationality to be stateless. See Bronwen Manby, Nationality and Statelessness Among Persons of Western Saharan Origin, 34 J. ImmigRATION, Asylum \& Nationality L. 9, 25-29 (2020).

76 See Carol Batchelor, Assessment of the \#IBelong Campaign Mid-point and the High-Level Segment on Statelessness, 1 StATELESSNESS \& Citizenship Rev. 307-08 (2019). 
While international legal efforts to counter this strategic production of statelessness have been diffused and infrequent, the examples in this Part have also been chosen to capture instances where international legal actors are beginning to mount challenges that have been partially successful in asserting limits to the state's prerogative to engage in statelessness production. These halting efforts, as Part III will go on to discuss, must be transformed into a bolder and more comprehensive international legal response to statelessness creep.

\section{A. Statelessness and Time}

Governance scholars have remarked on the nation-state "as an unexceptional container of time, as of space. States govern through temporal devices and rationalities, including censuses and other surveys, qualification periods for everything from citizenship to bus passes."77 Marking, measuring, and assigning political value to durational time - the ostensibly neutral and universal time of clocks and calendars-is intrinsic to the structuring and distribution of political power in liberal democracies. ${ }^{78}$ This political time is used to "carve sovereign boundaries around citizenries, as a means for measuring qualitative attributes of citizens, and for political exchange value through which amounts of time are demanded of individuals in exchange for rights." 79 The state's capacity to suspend, contract, expand, and accelerate durational time gives it the superpower to create and erase political membership not through the messy business of moving populations or physical boundaries, but through manipulating its counting of the abstract unit of time.

\section{Freezing Time}

State formation is an act inscribed not only in space but also in time: the physical boundaries of a state at the time of its founding often also simultaneously dictate who will be considered its citizens by demanding certain relationships between the individual and their physical location at a particular moment in time. In the words of Elizabeth Cohen, the temporal boundaries of state formation highlight how an individual's rights in relation to the state are not merely a function of who and where they are, but equally, when they happen to be there. ${ }^{80}$ The widespread temporal device of "zero option rules" acts as a sorting mechanism for differentiating between members of the polity and foreign others by specifying a cut off point for residence or physical presence on the territory that entitles one to citizenship. ${ }^{81}$ While facially neutral, by demarcating and freezing a population that is labeled as "native" on a certain date or dates, temporal deadlines can be used strategically by states to shape the ethnic, racial, religious, and linguistic composition of their population and create a class of quasi-citizens and stateless persons. ${ }^{82}$ Like time itself, this act of boundary drawing

${ }^{77}$ Melanie Griffiths, Ali Rogers \& Bridget Anderson, Migration, Time, and Temporalities: Review and Prospects (COMPAS Research Resources Paper, Mar. 2013).

${ }^{78}$ Elizabeth F. Cohen, The Political Value of Time: Citizenship, Duration, and Democratic Justice 1-4 (2018)

${ }^{79}$ Id. at 25 .

${ }^{80} I d$. at 5 .

${ }^{81}$ See Rainer Obliger, Ius Sanguinis, in 1 Immigration And Asylum: From 1900 to the Present 342, 342-46 (Matthew J. Gibney \& Randall Hansen eds., 2005).

${ }^{82}$ Noora Lori, Offshore Citizens: Permanent Temporary Status in the Gulf 94 (2019). 
is both backward and forward looking: temporal boundaries can harken back to a primordial vision of an original, true population to which the state seeks to return itself. They can signal a deliberate and violent break from the past where the population of the future is no longer shaped in the image of the past. And they can be used to set the terms of a newborn, imagined community that knows no past, but only the future. ${ }^{83}$

One such instance of temporal deadlines being used to ethnically engineer populations can be seen in the aftermath of the breakup of the Soviet Union, where states such as Latvia and Estonia granted automatic citizenship to individuals who were citizens or permanent residents of these states and their descendants prior to the period of Soviet occupation, rendering stateless thousands of ethnic Russians and other Russian-speaking minorities resident on their territories. ${ }^{84}$ In Estonia, these "individuals with undefined citizenship" constituting a third of the country's population could then either seek naturalization as Estonian citizens, opt for the citizenship of another country (including Russia), or simply continue to retain the status of "individuals with undefined citizenship." ${ }^{85}$ In Latvia, the 1994 citizenship law enacted after significant domestic political wrangling, provided for a "window system" for the naturalization of "non-citizens" with staggered time periods during which different categories of residents could apply for citizenship. ${ }^{86}$ Both states argued that their nationality laws were a decolonization measure intended to rectify discrimination against ethnic Estonians and Latvians during the period of Soviet occupation. ${ }^{87}$ Rather than an ethno-nationalist political project, the rhetoric was thus one of a rightful assertion of sovereignty and independence following decades of illegal occupation. ${ }^{88}$

Demanding naturalization requirements, especially those related to language proficiency, meant that the percentage of non-citizens remained fairly significant in both countries until the naturalization policies were softened under pressure from international and regional actors such as the Organization for Security and Co-operation in Europe, the Council of Europe, and the European Commission, in particular through policy recommendations championed by the Commission during the pre-accession process to the EU. ${ }^{89}$ However, as scholars have argued, the Commission largely refrained from questioning the ethnocentric state model adopted by both countries and focused narrowly on the mechanisms and procedures for naturalization instead of challenging the discriminatory grounds for citizenship acquisition. ${ }^{90}$ Political elites in Estonia as well as Latvia were thus spared from having to undertake major reforms in their citizenship policies in order to achieve their policy goals

${ }^{83}$ See CoHEN, supra note 78, at 43.

${ }^{84}$ Nida M. Gelazis, The European Union and the Statelessness Problem in the Baltic States, 6 Eur. J. Migration \& L. 225, 228-34 (2004).

${ }^{85}$ Priit Järve \& Vadim Poleshchuk, Country Report: Estonia, EUDO CitizENSHIP OBSERVATORY 1 (2013), available at https://cadmus.eui.eu/bitstream/handle/1814/19611/RSCAS_EUDO_CIT_2013_6.pdf?sequence=3\&is Allowed $=y$.

${ }^{86}$ See Kristine Krūma, Country Report on Citizenship Law: Latvia, EUDO Citizenship Observatory 6-7 (2015), available at http://hdl.handle.net/1814/34481.

${ }^{87}$ Gelazis, supra note 84, at 234-36.

${ }^{88}$ Vello Pettai \& Klara Hallik, Understanding Processes of Ethnic Control: Segmentation, Dependency and Co-optation in Post-communist Estonia, 8 Nations AND Nationalism 505, 510-11 (2002).

${ }^{89}$ Järve \& Poleshchuk, supra note 85 , at 13.

90 See Dimitry Kochenov, EU Influence on the Citizenship Policies of the Candidate Countries: The Case of the Roma Exclusion in the Czech Republic, 3 J. Contemp. Eur. Res. 124, 139 (2007). 
of entry into the EU and NATO. ${ }^{91}$ International pressure to resolve the situation of non-citizens in the two countries has since ceased - arguably because this would involve international actors admitting their own failures and oversights ${ }^{22}$ - and the issue has been relegated to domestic politics, where this class of non-citizens has gradually acquired greater rights and privileges that nonetheless stop short of full citizenship. ${ }^{93}$

As Estonian and Latvian cases show, zero-options rules that are argued to be part of the decolonization process present a particularly challenging case for addressing the statelessness that follows. From Asia to Africa to Latin America, newly independent states have inherited artificial borders that were put in place by colonial powers. These state boundaries were imposed in disregard of pre-existing geopolitical realities, arbitrarily grouping together peoples from diverse communities within a single territorial state and simultaneously dividing political, cultural, religious, and ethnic polities into separate territorial units. ${ }^{94}$ The legacy of these colonial boundaries lives on in the ways in which nationality is conceived and transmitted in post-colonial states, putting certain groups at risk of statelessness. In the UAE, for instance, the 1971 law of citizenship has sought to limit UAE citizenship to persons who can trace their ancestry to the 1925 Arab tribes documented by the British census, requiring nonArab minorities such as Persians, East Africans, and South Asians to undergo naturalization and resulting in a limbo population that is not counted as citizens even if their families have been settled in the country for generations. ${ }^{95}$

The invocation of temporal deadlines to resolve contestations over which groups are entitled to membership in newly formed and modernizing nations has been particularly fraught in the African context. Notwithstanding the egregious colonial drawing of the political map in Africa, African states elected to preserve the borders in place at the time of their independence through the Organization of African Unity's 1964 Cairo Declaration on Border Disputes Among African States, affirming Member States' commitment to "respect the borders existing on their achievement of national independence." 96 This decision has been criticized in various quarters as indefensibly ahistorical and a catalyst for future conflicts. However, it has also been defended as a pragmatic solution to avoid armed conflicts over territorial disputes by putting existing territorial borders in a "holding pattern" to facilitate peaceful resolution of territorial disputes between African states. ${ }^{97}$ While these geographical borders and the populations they demarcate have for the most part proved stable in post-colonial states, decolonization of constituent populations has instead been attempted through changes in temporal borders, negatively impacting populations that are considered non-native and placing them at risk of statelessness.

${ }^{91}$ James Hughes, "Exit" in Deeply Divided Societies: Regimes of Discrimination in Estonia and Latvia and the Potential for Russophone Migration, 43 J. COMMON MARKET STUD. 739, 759 (2005).

92 Id. at 756

93 See Järve \& Poleshchuk, supra note 85, at 1; Krūma, supra note 86, at 10-11.

${ }^{94}$ On the continuing legacy of artificial borders, in particular in Africa and the Middle East, see Tim MarshaLl, Prisoners of Geography: Ten Maps that Explain Everything About the World (2015).

${ }^{95}$ LORI, supra note 82, at 94.

${ }^{96}$ Organization of African Unity, Border Disputes Among African States, AHG/res. 16(I), Assembly of Heads of State and Government Meeting in Its First Ordinary Session in Cairo, UAR, 17-21 July (1964).

97 See Frontier Dispute (Burk. Faso v. Niger), 2013 ICJ Rep. 134, paras. 16-19 (Apr. 16) (sep. op., Yusuf, J.). 
One way to accomplish this resetting of the population to a previous self that preceded the colonial encounter is domestic constitutional and legal arrangements and state practice that make citizenship contingent on membership in "tribes" that pre-date colonial population transfers. A striking instance of the resulting statelessness was made visible in the African Commission on Human and People's Rights decision holding that Côte d'Ivoire had violated the right to nationality of members of the Dioula ethnic community. ${ }^{98}$ The complaint hinged on the 1961 Ivorian Nationality Code's adoption of the jus soli principle for grant of nationality defining an Ivorian national as an individual who could trace her ancestry to an Ivorian at the time of independence. However, since the Code failed to define who counted as an "Ivorian," or as a foreigner, this gave the state the discretion to introduce discriminatory nationality practices under the doctrine of "Ivoirité." This doctrine was based on the concept of an authentic Ivorian heritage whereby indigenous Ivorians were to be distinguished from "foreign" immigrants from the North who were not entitled to Ivorian nationality. ${ }^{99}$ Labeling the Dioula people as foreign migrants, state authorities refused to issue them with documents verifying their legal status such as birth certificates and identity cards and destroyed previously issued documents. The Commission held that this discriminatory interpretation of the nationality law by the state authorities led to thousands of residents who had been born in Côte d'Ivoire, and to parents who were also born in Côte d'Ivoire, becoming stateless. ${ }^{100}$

While the successful challenge to Côte d'Ivoire's attempt to exploit the ambiguity in its nationality laws to create a class of stateless Dioula "immigrants" seems like a true victory for regional human rights institutions--in 2020, Côte d'Ivoire even became the first African country to adopt a national Statelessness Determination Procedure ${ }^{101}$ - it is important to bear in mind that this success story played out against the backdrop of favorable domestic political winds. The period between 2006, when the case was brought before the Commission, and 2015, the delivery of the decision, saw the election of President Alassane Ouattara, who had himself previously been accused of not being a native Ivorian citizen and faced significant difficulties in proving his eligibility to run for political office. Unsurprisingly, the reform of nationality laws was not only a legal, but equally a personal, project for President Ouattara, who introduced amendments to nationality laws, simplified procedures for access to nationality and the issuance of identity documents, and initiated Côte d'Ivoire's accession to the Statelessness Conventions, measures that were undertaken before the Commission issued its decision. ${ }^{102}$ It is thus unclear what lessons international legal actors working to combat statelessness can learn from the Côte d'Ivoire example, an issue that this Article will revisit in Part III.

Indeed, international and regional actors have struggled to devise an effective response to another case of statelessness also engineered by a countdown deadline: denial of citizenship to the Rohingya by the government of Myanmar. The 1982 Burmese Citizenship Law grants

\footnotetext{
98 Open Society Justice Initiative v. Côte d'Ivoire, Comm. 318/06, 17th Extraordinary Sess., Feb. 19-28, 2015.

${ }^{99}$ Id., paras. 53-54, 116-18.

${ }^{100}$ Id., paras. 119-20.

${ }^{101}$ UNHCR Press Release, Côte d'Ivoire Adopts Africa's First Legal Process to Identify and Protect Stateless People (Sept. 4, 2020), at https://www.unhcr.org/news/press/2020/9/5f51f33b4/cote-divoire-adopts-africasfirst-legal-process-identify-protect-stateless.html.

${ }^{102}$ For a detailed history of the political history of Côte d'Ivoire's nationality laws, see MANBY, supra note 70, at 207-20.
} 
citizenship to individuals belonging to one of the 135 "national groups" with permanent homes in the state territories before 1823. The government argues that the Rohingya are not "native" to Burma but illegal Bengali immigrants. Since they do not constitute one of the 135 recognized national races, they are not entitled to full Burmese citizenship. ${ }^{103}$ While there have been some formal legal efforts responding to Myanmar's discriminatory treatment of the Rohingya prompted by the 2017 atrocities and forced displacement of thousands of Rohingya, they have mostly focused narrowly on the question of accountability for international crimes committed against the Rohingya. Three such proceedings have been running in parallel before different institutions. The first is the Independent Investigative Mechanism for Myanmar set up in 2018 with the mandate to "collect, consolidate, preserve and analyse evidence of the most serious international crimes and violations of international law committed in Myanmar since 2011. ..," such that this evidence can be used in criminal proceedings. ${ }^{104}$ Simultaneously, the prosecutor of the International Criminal Court (ICC) has opened investigations into the Bangladesh/Myanmar situation focusing on crimes against humanity, though these will only cover alleged crimes against the Rohingya which took place, at least in part, on the territory of Bangladesh as a state party to the Rome Statute of the ICC. ${ }^{105}$ Third, proceedings have been instituted before the International Court of Justice (ICJ) by the Gambia against Myanmar alleging violations of the 1948 Genocide Convention. In January 2020, the ICJ ruled in favor of the Gambia's request for provisional measures, ordering Myanmar to comply with its obligations under the Convention, report on their implementation, and take measures to preserve evidence. ${ }^{106}$

These proceedings have thus far failed to ameliorate the situation of the Rohingya, in particular as concerns the resolution of their statelessness. As late as September 2021, the UN special rapporteur on the situation of human rights in Myanmar, accused the junta regime that came into power following the military coup of February 2021 of continuing to "deny the existence of the Rohingya ethnic minority." ${ }^{07}$ Indeed, legal advocates fear that a failure to manage expectations as to what these proceedings can deliver in terms of a path to citizenship for the Rohingya can end up backfiring: "[i]f you allow the Rohingya to believe that the international courts are in a position to grant them citizenship directly, then these processes are set up to be perceived as failures before they have even started." 108 Part III reflects on what this experience might mean for future international litigation efforts to address statelessness.

As the above examples show, zero-option laws premised on time as currency typically rely on highly juridical arguments invoking notions of state continuity, illegal occupation, and reclaiming of sovereign authority. And those that are associated with decolonization and

103 Kelly Staples, Retheorising Statelessness: A Background Theory of Membership in World Politics 139 (2012).

${ }^{104}$ Human Rights Council, Res. A/HRC/RES39/2, para. 22 (Oct. 3, 2018).

105 Situation in the People's Republic of Bangladesh/Republic of the Union of Myanmar, Case No. ICC-01/19-27, Decision Pursuant to Article 15 of the Rome Statute on the Authorisation of an Investigation into the Situation in the People's Republic of Bangladesh/Republic of the Union of Myanmar, Pre-Trial Chamber III (Nov. 14, 2019).

106 Application of the Convention on the Prevention and Punishment of the Crime of Genocide (Gamb. v. Myan.), Request for Provisional Measures, 2020 ICJ Rep. 3 (Jan. 23).

${ }^{107}$ Myanmar: UN Expert Says Current International Efforts Failing, Urges “Change of Course, "UN News (Sept. 22, 2021), at https://news.un.org/en/story/2021/09/1100752.

${ }^{108}$ Verena Hölzl, Three Years After Rohingya Exodus, Mismatched Expectations of Justice, New HumanitARIAN (Aug. 24, 2020), at https://www.thenewhumanitarian.org/news-feature/2020/08/24/Bangladesh-MyanmarRohingya-international-justice. 
the rhetoric of return to an authentic, true, polity may even invite sympathy in some quarters, complicating efforts to identify and address the statelessness that ensues in their wake.

\section{Excising Time}

For those who do not pass through the gates of the nation at the time of its birth, the entitlement to become part of the political community is contingent on demonstrating ties with the community. A key element in proving these ties is through residence in the state. While states use various criteria such as family and social relationships, linguistic skills, and knowledge of culture, institutions, and social practices to measure prospective citizens' embeddedness in and loyalty to the community, these are typically over and above the requirement of physical presence over an extended period of time in the community. Time can be assigned this political value due to its ability to serve as an ostensibly neutral proxy for hard-to-measure criteria such as fidelity, cultural assimilation, and civic virtue. ${ }^{109}$ Different lengths of residence can be imbued with different political values and used as a form of exchange to accord or deny the right of citizenship depending on the duration of residence. ${ }^{110}$ Indeed, while criteria such as citizenship tests or demanding language requirements are often criticized for their exclusionary character, it is generally assumed that it is reasonable and fair for a state to use time as a factor to distribute the precious good of citizenship.

What matters for citizenship however, is not always the physical, chronological time that an individual may have spent on the territory, but rather how the state counts that time. The legal value assigned to time can be used strategically to exclude, suspend, or fast-track potential applicants in the queue for citizenship. ${ }^{111}$ Not only can states discount time spent illegally on the territory for establishing residence, but they can also enact and interpret legal concepts to erase the physical time for which an individual has lived within their boundaries for the purposes of nationality acquisition. ${ }^{112}$

The Dominican case of the Haitian migrants and Dominicans of Haitian descent is a prominent example of statelessness resulting from the distinction between the passage of chronological time on state territory and its legal counting for the purposes of citizenship entitlement and represents one of the few instances of statelessness to have been successfully litigated before an international court, the IACtHR. The case of Girls Yean and Bosico $v$. Dominican Republic concerned the Dominican Republic's refusal to issue birth certificates to the applicants who had been born on its territory, thereby denying them the nationality of the Dominican Republic which recognizes the principle of jus soli for grant of citizenship. ${ }^{113}$ The court held that this denial was a violation, among others, of the right to nationality under Article 20 of the American Convention on Human Rights. ${ }^{114}$

According to the court, the right to nationality was a fundamental, non-derogable right under the Convention and a prerequisite for the exercise of other Convention

109 CoHen, supra note 78 , at 8 .

110 Noora Lori, Migration, Time, and the Shift Toward Autocracy, in The ShIFTING Border: Legal Cartographies of Migration and Mobility 121-22 (2020).

111 Id. at 119.

$112 \mathrm{Id}$. at $119,122-23$.

113 The Girls Yean v. Dominican Republic, supra note 69.

${ }^{114}$ American Convention on Human Rights, Nov. 22, 1969, OASTS No. B-32, 1144 UNTS 123. 
rights. ${ }^{115}$ While the state retained authority over the determination of nationality questions, its discretion in this respect was circumscribed by the duty to guarantee to individuals the equal protection of law and the obligation to avoid statelessness. ${ }^{116}$ Moreover, in light of the peremptory norm on equal protection and non-discrimination, states were under an obligation to refrain from enacting discriminatory laws and practices regulating nationality and to take active measures to promote equal protection under the law. ${ }^{117}$ States were also prohibited from adopting laws and practices for the grant of nationality that lead to an increase in statelessness. Statelessness could arise "from the lack of a nationality, when an individual does not qualify to receive this under the State's laws, owing to arbitrary deprivation or the granting of a nationality that, in actual fact, is not effective."118

Applying these international norms to the law and practice of the Dominican Republic on the issuance of birth certificates, the court noted that the Dominican Constitution followed the principle of jus soli for the grant of nationality with the exception of children of diplomats and foreigners who are "in transit." State authorities in the Dominican Republic considered Haitian migratory workers to be in transit and thus treated their children who were born in the Dominican Republic as not entitled to Dominican nationality. Relying on domestic court interpretations of the phrase "in transit" and the international obligation of non-discrimination irrespective of an individual's migratory status, the court held that an individual's migratory status was not sufficient justification for denying them the right to nationality. Further, this status could in any case not be transferred to the children of migrants and individuals had a right to nationality by birth of the state where they were born if they did not have the right to any other nationality. ${ }^{119}$

In this case, the state had applied procedures for the issuance of a birth certificate in a manner that was arbitrary and-especially in light of the vulnerable situation of Haitian migrants and Dominican nationals of Haitian origin — discriminatory, placing the applicants in a situation of statelessness and extreme vulnerability. The state was therefore obligated to take affirmative steps to ensure that the applicants could access birth registration procedures that were reasonable, and in conditions of equality, so as to fully exercise their right to nationality. ${ }^{120}$

The judgment and various remedial and reparative measures ordered by the court failed, however, to have the desired impact on nationality legislation in the Dominican Republic. Indeed, the situation became even worse with a 2013 ruling of the Dominican Constitutional Court ordering executive review and retroactive withdrawal of the Dominican citizenship of children born on the territory of the Dominican Republic whose parents who did not have a regular migration status in the country, rendering stateless tens of thousands of Dominicans of foreign descent. ${ }^{121}$ One year later, this led to the IACtHR

${ }^{115}$ The Girls Yean v. Dominican Republic, supra note 69, paras 137-38.

${ }^{116} I d$., para. 140.

${ }^{117}$ Id., para. 141.

${ }^{118} I d$., para. 142.

${ }^{119}$ Id., paras. $150-56$.

${ }^{120}$ Id., paras. $165-71$.

${ }^{121}$ Dinah Shelton \& Alexandra Huneeus, In Re Direct Action of Unconstitutionality Initiated Against the Declaration of Acceptance of the Jurisdiction of the Inter-American Court of Human Rights, 109 AJIL 866, 868 (2015). 
judgment in the case of Expelled Dominicans and Haitians v. Dominican Republic, addressing the arbitrary detention and expulsion of Haitians and Dominicans of Haitian descent from the Dominican Republic and the barriers to registering and obtaining nationality for individuals of Haitian descent born in the Dominican Republic. ${ }^{122}$ As part of its legal analysis, the court undertook an extensive factual analysis of the discrimination faced by Haitian migrants and Dominicans of Haitian descent, which also impacted their ability to obtain official identity documents. The attainment of a birth certificate-which was a requirement for obtaining nationality — was difficult both due to the social conditions in which these births took place as well as discriminatory official practices that accompanied efforts to register births with the authorities and the suspicion that attached to the subsequent use of these documents. ${ }^{123}$

The court then turned to the right to nationality under Article 20 of the Convention and reiterated its holding in Girls Yean and Bosico on the scope and importance of the right, adding that if the state is not certain that a child born in its territory would be able to obtain the nationality of another state, whether for formal legal reasons, or due to de facto obstacles, it is obligated to grant nationality in order to avoid statelessness at birth. ${ }^{124}$ Notwithstanding the interpretation of the nationality laws by the Dominican Constitutional Court, "basic standards of reasonableness" had to be met when evaluating the state's obligations under the American Convention. Domestic constitutional amendments and court cases had held that migrants in an irregular situation should be considered as "aliens in transit" irrespective of the length of their physical presence on the territory as distinguished from the period of ten days that applied to the separate category of "transient aliens." 125 In line with its previous decision in Girls Yean and Bosico, and contrary to the decision of the Constitutional Court, the court thus held that "to consider a person ... in transit ... the State must respect a reasonable time frame, and be coherent with the fact that an alien who develops ties in a State cannot be compared to a transient or to a person in transit." 126 Furthermore, since the state had not proved that these individuals would in fact be able to acquire the nationality of another state-in this case, Haiti-its decision to deprive them of the nationality of the Dominican Republic risked rendering them stateless and violated their right to nationality and related Convention rights, including the right to recognition of juridical personality, the right to a name, and the right to identity. ${ }^{127}$

The ruling, which was hailed as an important moment for putting issues of arbitrary deprivation of nationality on the international legal and political map, has, however, failed to have the desired impact not only internationally, but also on home territory. The Dominican Republic's executive branch moved immediately to reject the ruling and subsequent official public statements have reiterated the fiction that the Dominican Republic has no stateless persons and that the existing legal framework is adequate for protecting those who might be at risk of statelessness. ${ }^{128}$ Even the limited legal measures to address statelessness

${ }^{122}$ Expelled Dominicans and Haitians v. Dominican Republic, supra note 69.

${ }^{123}$ Id., paras. 163-66.

${ }^{124} I d$., paras. 253-61.

${ }^{125} \mathrm{Id}$., paras. 282-88.

${ }^{126} I d$., para. 294.

${ }^{127}$ Id. paras. 286-99.

${ }^{128}$ See Bridget Wooding, Seizing New Opportunities to Address Statelessness in the Dominican Republic, Eur. Network Statelessness Blog (Nov. 19, 2020), at https://www.statelessness.eu/updates/blog/seizing-newopportunities-address-statelessness-dominican-republic. 
introduced by the Dominican Republic following the severe criticism of the 2013 constitutional decision, and that were judged to be flawed and insufficient in Expelled Dominican, have been sought to be repealed by nationalist groups. ${ }^{129}$ Procedures for obtaining the relevant identity documents continue to be characterized by both structural discrimination against Haitian migrants and Dominicans of Haitian descent and additional barriers imposed by individual offices and officials at their discretion. ${ }^{130}$ According to some estimates, the Dominican Republic remains the "single largest case of statelessness in Latin America."131

A more successful regional intervention, albeit one that was dependent on domestic legal efforts for resolution of statelessness, was the pilot judgement of the European Court of Human Rights (ECtHR) concerning the situation of stateless persons in Slovenia. ${ }^{132}$ This class of stateless persons was the outcome of a strategic legalistic effort by the Republic of Slovenia to mark time differently for eligibility for citizenship following its independence from the former Yugoslavia. Under the new citizenship law of Slovenia, citizens of other former Yugoslav republics who were permanent Slovenian residents could acquire Slovenian citizenship by lodging an application within six months provided they had been Slovenian permanent residents on the day Slovenia held a plebiscite on independence. This effectively excluded from citizenship citizens of other former Yugoslav republics who had habitually resided and worked in Slovenia but who were not registered as immigrants in Slovenia and therefore did not count as permanent residents. Moreover, even registered immigrants in Slovenia who did not apply for citizenship within the six-month period or those whose applications for citizenship were rejected were deemed foreigners rather than residents under the provisions of the Aliens Act. Their records were struck from the register of permanent residents and transferred to the aliens register without any notice. This population of mainly nonethnic Slovenes, some of whom had been born in Slovenia and others who had been living there for several decades, became known as the "erased," becoming de facto aliens or stateless persons illegally residing in Slovenia. ${ }^{133}$

Following significant civil society mobilization, this erasure was challenged and held to be unconstitutional by the Slovenian domestic courts, following which Slovenia amended its laws to permit more of those whose records had been deleted to apply for permanent residence. The ECtHR deemed these remedies to be inadequate and as perpetuating the state of limbo for a significant percentage of the erased. It awarded the applicants non-pecuniary damages for their rights violations resulting from the situation of legal uncertainty and vulnerability, ordered Slovenia to establish a domestic compensation scheme, and subsequently handed down a just satisfaction judgment for pecuniary damages. ${ }^{134}$ In 2016 , the Council of Europe's Committee of Ministers, which is responsible for supervising the implementation of the ECtHR's judgements, declared itself satisfied that all the measures required had been

\footnotetext{
${ }^{129}$ Dominicanos por Derechos, The Institute on Statelessness and Inclusion \& The Center for Justice and International Law, Joint Submission to the Human Rights Council at the 32nd Session of the Universal Periodic Review: The Dominican Republic, paras. 22-23, 31 (July 12, 2018), available at https://files.institutesi.org/ UPR32_DominicanRepublic.pdf.

${ }^{130} I \bar{d}$., paras. 24-32.

131 Wooding, supra note 128.

132 Kurić and Others v. Slovenia, 2012-IV Eur. Ct. H.R. 1 [hereinafter Kurić 2012].

${ }^{133}$ Vlasta Jalušič \& Jasminka Dedić, (The) Erasure - Mass Human Rights Violation and Denial of Responsibility: The Case of Independent Slovenia, 9 Hum. RTs. REV. 93, 94-96 (2008).

${ }^{134}$ Kurić 2012, supra note 132; Kurić and Others v. Slovenia, Eur. Ct. H.R. 2014.
} 
adopted and closed its examination of the case. ${ }^{135}$ However, critics argue that a sizeable number of the erased were unable to restore their legal status and were disqualified from claiming compensation. These include individuals who were deported from, or denied re-entry into, Slovenia pursuant to the loss of status. There is also little political will or momentum to attend to these cases any longer. ${ }^{136}$ As Part III will argue, the varying impact of progressive rulings by the IACtHR and ECtHR on statelessness on the ground holds important lessons for actors pursuing statelessness litigation before supranational courts.

Similar to the act of freezing time, excising time does not involve physically expunging persons from the territory of the state. Rather, physical erasure is achieved through temporal erasure whereby the state manipulates chronological time by making the temporal credit for the physical time spent on the territory contingent on the particular legal status of the individual during this period.

\section{Dead Time}

Between those who pass through the gates of citizenship and those who are turned away lies another category of persons who are effectively stateless: those who are kept waiting indefinitely at the gate. States control and tamper with the temporal register not only through freezing and excising time but equally through its suspension. Like Kafka's "man from the country," individuals waiting at the temporal borders of citizenship may wait patiently at the border their entire life, pestering, cajoling, and bribing the guards to let them in, only to discover near the end that the gate had been meant for them alone and would cease to exist with their death. ${ }^{137}$ While waiting can be the result of incompetence and bureaucratic delays on the part of the state, waiting can also be a deliberate state tactic to continuously defer citizenship. ${ }^{138}$

Conceptualizing waiting, not as a "by-product of state institutions and bureaucracies" but as a "management technique that is not outside but fully part of the state," 139 highlights the ways in which the state can use delays, deferrals, and postponements to exercise power over putative citizens. While waiting is a universal human experience, each individual experiences waiting in his own way depending on his position in the social hierarchy. Waiting time is unequally distributed with those at the top of the social system waited upon by those at the bottom who do the most waiting. ${ }^{140}$ Waiting can be both a form of inducing compliance and a form of sanctioning by the state. As Auyero's ethnographic account of welfare clients waiting in the welfare office shows, the arbitrariness and uncertainty that characterizes this

\footnotetext{
${ }^{135}$ Committee of Ministers, Resolution CM/ResDH(2016)112, Execution of the Judgments of the European Court of Human Rights, Kurić and Others Against Slovenia, 1257th Meeting of the Ministers' Deputies (May 25, 2016), at http://hudoc.echr.coe.int/eng?i=001-163580.

${ }^{136}$ Ginger Hervey, Justice Evades Slovenia's “Erased” Citizens, Politico (Mar. 28, 2017), at https://www.politico.eu/article/justice-evades-slovenia-erased-citizens-yugoslavia; Anja Vladisavlj, Status Revoked: Slovenia's "Erased" Recall Long Struggle for Justice, Balkan Transitional Just. (Feb. 26, 2021), at https://balkaninsight. com/2021/02/26/status-revoked-slovenias-erased-recall-long-struggle-for-justice.

137 See Mariane C. Ferme, Introduction: Localizing the State, 86 AnTHropological Q. 957, 958 (2013).

${ }^{138}$ LORI, supra note 82, at 6.

${ }^{139}$ Roos Pijpers, Waiting for Work: Labour Migration and the Political Economy of Borders, in THE AsHGATE Research Companion to Border Studies 417, 432 (Doris Wastl-Walter ed., 2011).

${ }^{140}$ Barry Schwartz, Waiting, Exchange, and Power: The Distribution of Time in Social Systems, 79 Am. J. Soc. $841,844,847$ (1974).
} 
waiting zone reinforces poor people's conviction that instead of negotiating with the authorities, their only hope for welfare relief is to be patient and comply with the authorities' dictates. ${ }^{141}$ Beyond the feelings of dependence and subordination that waiting engenders, an individual who is kept waiting indefinitely without any indication of how long this wait may last or whether it will have any concrete outcome may even experience waiting as a form of punishment. ${ }^{142}$

The de facto statelessness of individuals who find themselves in this condition of state engineered precariousness can be seen in Noora Lori's superb analysis of migrant populations who occupy a limbo status in the UAE either because their naturalization cases are continuously adjourned by the state or because they are assigned visa statuses that are intended to be temporary but are continuously renewed without, however, bringing them any closer to eligibility for citizenship. ${ }^{143}$ Lori refers to the kafala system, the guest worker program of the UAE which brings temporary contractual laborers to the UAE with the intention of meeting short term labor demands in a particular sector. While these temporary contractual laborers are expected to leave once these short-term needs are met and are hence not eligible to apply for permanent residence or citizenship, in practice, their residency is constantly extended through labor contracts that are renewed by domestic sponsors. This has a created a class of non-citizen residents who have been settled in the UAE - at times for several generations - while formally being considered "temporary" by the UAE. ${ }^{144}$ In the absence of any formal rights of permanent residence or citizenship, these "guests" to the UAE are deportable at the discretion of the government notwithstanding their ties to the country. ${ }^{145}$

In addition to excluding guest workers from citizenship, the UAE also employs delaying tactics to indefinitely postpone the citizenship of otherwise eligible individuals. Since all UAE residents, including UAE born residents, who cannot trace their lineage to the Arab tribes of 1925 are obligated to go through a naturalization process, one way to defer citizenship is by refusing to either approve or deny the naturalization application. While the naturalization process can legally be initiated after seven years of residence, in practice, naturalization applications of even individuals who have lived in one of the emirates for decades continue to be in abeyance, incentivizing them to persist in their engagement with the state in the hope of an eventual resolution. ${ }^{146}$

From the state's perspective, the tactic of indefinite postponement is infinitely superior to one of outright citizenship denial. Not only is this permanently "temporary" status invisible to the international legal framework on statelessness, but persuading would-be citizens to engage in a perpetual waiting game where their patience and labor may be rewarded with the benefits of citizenship serves the state's economic purposes while allowing it to avoid difficult or unpopular political judgments on state membership, identity, and inclusion. ${ }^{147}$

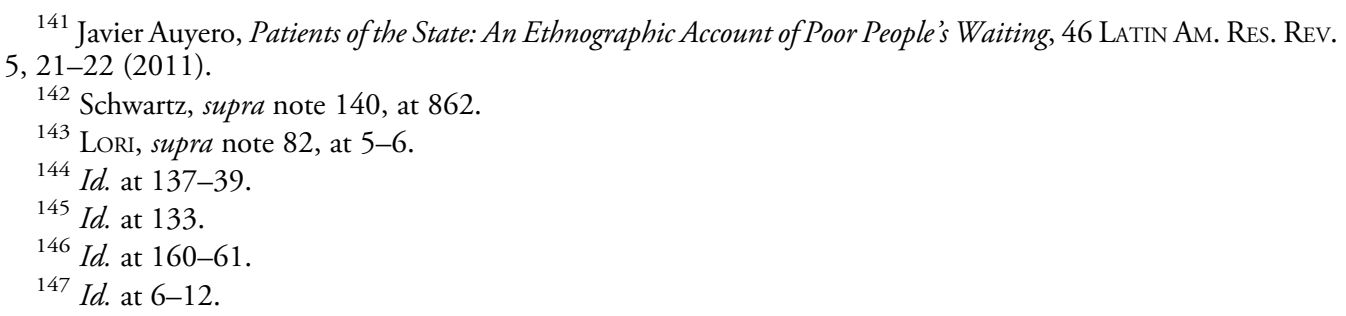




\section{B. The Spatiality of Statelessness}

The modern nation-state is premised on the notion of stability of territorial borders that are fixed in both time and place. While there have been numerous legal attempts to address the statelessness that can result when these borders come under stress during periods of state dissolution, succession, and transfer of territory, what is seldom acknowledged is that, even in normal times, the state's boundaries can be discontinuous, contingent, and unstable. ${ }^{148}$ Rather than fixed lines on a map that fit neatly together to demarcate the exclusive domains of territorially circumscribed sovereign authority, state borders constitute a landscape of time and space that is portable and porous, that the state can continuously make and unmake through legal constructs. ${ }^{149}$ Scholarship on statelessness has failed to grasp the extent to which this legal fortification and reinvention of the spatial border can be used to redefine the principles along with political membership can be allocated, distributed, and rescinded by states. One example of this faith in spatial stability are legal advocacy efforts seeking to persuade states to adopt the jus soli principle for citizenship as one of the primary pathways for avoiding statelessness. ${ }^{150}$ While citizenship based on jus soli would go some way to prevent statelessness in certain countries, it nonetheless presupposes a clearly demarcated physical territory with stable borders rather than one characterized by a multitude of shifting borders that are negotiated and renegotiated during processes of admission to political membership. ${ }^{151}$

\section{Perforating Borders}

In dissecting the time-space nexus in the construction of political borders, Cohen draws on the little known historical usage of the word "deadline," which originally did not signify a time limit for the completion of a task, but rather the perimeter around a military prison that the prisoner was forbidden to cross on pain of getting shot. The deadline was thus a territorial limit, which permitted the state to make life-and-death decisions over the bodies under its control. ${ }^{152}$ Modern state territorial boundaries too can serve a life-and-death function by acting as a sorting device by which the state categorizes individuals into citizens who fall within these boundaries and the foreigners without who have no entitlement to the protection of the state and its political institutions. However, territorial borders are not merely a function of geography but also of the law and legal institutions that the state sets up to define and police these borders. ${ }^{153}$ In the evocative language of Ayelet Shachar, to prevent individuals from crossing-literally and metaphorically — through its borders, the state may even go to the lengths of excising its own territory and creating exceptional zones, as if it were "perforating itself geographically." 154

\footnotetext{
148 See Ferme, supra note 137, at 958.

149 See Ayelet Shachar, The Shifting Border: Legal Cartographies of Migration and Mobility, in THE SHIFTING BORDER, supra note 110, at 4-6.

${ }^{150}$ See Weissbrodt \& Collins, supra note 49, at 256.

151 See Alison Kesby, The Shifting and Multiple Border and International Law, 27 OXFORD J. LEG. STUD. 101, 102-03 (2007).

152 CoHEN, supra note 78, at 29-30.

153 See Kesby, supra note 151, at 110 .

154 Shachar, supra note 149 , at 43.
} 
The borderlands of states are one such zone of exception where spatiality can be legally reconfigured to produce citizens and stateless foreigners. Contestations over citizenship in borderlands may be a legacy of artificially constructed borders during colonization, state dissolution and transfer of territory, or population flows due to political instability and market imperatives.

The curious case of persons living in "enclaves" and consigned to de facto statelessness is one instance of this contestation. Largely ignored as "footnotes to the history of state formation," 155 enclaves are segments of a state's territory that are fully enclosed by another state's territory. Though enclaves were somewhat frequent in the early period of Westphalian nation-state formation, modern enclaves are few and far between. Until recently, the vast majority of enclaves in the world existed on the borderlands of India and Bangladesh, a result of the independence and partition of British India into India and what was then East Pakistan (now Bangladesh) in 1947. ${ }^{156}$ Forming fissures in the territories of each of these states, they came to be treated as non-state spaces, inhabited by islands of putative citizens who were ungoverned by either the state of their formal citizenship (the home state) or the state within whose territory they were resident (the host state). Not only did each state often deny access to officials of the other state to their own enclave for administrative purposes, but inhabitants of the enclaves were also largely trapped inside the enclaves, unable to move freely outside the enclave and cut off from the life of the host state. ${ }^{157}$ Lacking all the trappings of citizenship such as a birth certificate, identity card or passport, or access to state facilities and social services, enclave inhabitants were abandoned by both their home state and the host state in the non-state space of the enclave. ${ }^{158}$

Although an initial attempt was made to absorb these enclaves into the territory of the surrounding territorial state through the 1958 Nehru-Noon Accords between India and Pakistan, the issue of the enclaves became mired in political opposition given the volatile relationship between India and Bangladesh. It was only in 2015 that the two countries implemented a decades-old agreement to exchange the enclaves, with enclave residents being given the choice to acquire the citizenship of their host state or "return" to the home state of their formal citizenship. ${ }^{159}$ While the exchange has formally resolved the statelessness of enclave inhabitants, the former status of the enclaves as abandoned spaces means that the work of constructing the apparatus of the state around these new citizens who lack both affective and material ties to the states of their citizenship will prolong their limbo status for some time to come. ${ }^{160}$ Recent reports show that the effects of the nearly seven decades of statelessness experienced by enclave residents still persist. Though they now possess certain formal markers of citizenship such as voter identification cards, the government has largely failed to provide them with land documentation and rehabilitation measures crucial to their

\footnotetext{
155 See Willem van Schendel, Stateless in South Asia: The Making of the India-Bangladesh Enclaves, 61 J. AsIAN STUD. 115, 139 (2002).

${ }^{156} \mathrm{Id}$. at $116-17$.

157 Id. at $124-26$.

${ }^{158}$ Hosna J. Shewly, Abandoned Spaces and Bare Life in the Enclaves of the India-Bangladesh Border, 32 POL. GEO. 23, 24, 27 (2013).

${ }^{159} \mathrm{Md}$. Azmeary Ferdoush \& Reece Jones, The Decision to Move: Post-Exchange Experiences in the Former Bangladesh-India Border Enclaves, in Routledge Handbook of Asian Borderlands 255, 257-59 (Alexander Horstmann, Martin Saxer \& Alessandro Rippa eds., 2018).

${ }^{160} \mathrm{Id}$. at 263.
} 
livelihoods, resulting in continuing difficulties with accessing the rights and privileges attendant on citizenship. ${ }^{161}$

Though enclaves may constitute a rather exceptional phenomenon of perforated borders, borderlands also yield other forms of state-manufactured statelessness and liminality. The "hill tribes" of Thailand, the official category used by the Thai state to designate various ethnic groups living in the uplands of the Thai borderland, are another example of subjects without citizenship. ${ }^{162}$ The highlanders have been constructed by the Thai state as "wild non-Thai others" living in the peripheral uplands as a way of reinforcing the Thai-ness of lowland Thais who constitute the core of the nation-state. ${ }^{163}$ Labeling the highlanders variously as insurgents, opium producers, and forest destroyers who threatened the security of the state, the government officially classified and registered them as "hill tribes" in the mid-twentieth century, followed by severe restrictions on their mobility and land use throughout the twentieth century. ${ }^{164}$

Following the official classification of hill tribes, Thailand made various efforts to accurately count and identify this population for administrative purposes. Numerous population surveys and registration campaigns were carried out to document and register highlanders and special color coded identity cards were issued to grant them semi-permanent residency. However, due to lack of knowledge of the terrain, lack of resources and administrative capacity, and problems with processing the data, these surveys were far from complete and many highland villages were never found or registered, excluding inhabitants from identity documents signifying rights of residence. ${ }^{165}$ The administrative non-existence of highland minority villages in the official territory of the Thai state has thus produced several generations of highlanders who the state does not even register as hill tribes, thus excluding them from Thai citizenship. ${ }^{166}$

And even for the highlanders who were registered, this did not grant them automatic citizenship on the basis of either jus soli or jus sanguinis, but only entitled them to subsequent citizenship by naturalization. ${ }^{167}$ In the absence of proof of registration, the primary way for stateless highlanders who have been physically resident in Thailand for generations to qualify for Thai citizenship is through officially documented proof of birth on the territory before the date of February 26, 1992, which the majority of them lack. ${ }^{168}$ As scholars note, the Thai state has largely refused to acknowledge the reasons for the lack of this documentation and has persisted in demanding evidence that most elderly highlanders do not possess, resulting in a situation where they have no path to citizenship. ${ }^{169}$

${ }^{161}$ See Shiv Sahay Singh, 5 Years After Land Border Agreement, Former Enclave Dwellers in Dire Straits, HINDU (Aug. 3, 2020).

${ }^{162}$ Mika Toyota, Subjects of the Nation Without Citizenship: The Case of "Hill Tribes" in Thailand, in Multiculturalism in Asia 110, 111 (Will Kymlicka \& Baogang He eds., 2005).

${ }^{163} \mathrm{Id}$. at 115 .

${ }^{164}$ Amanda Flaim, Daniel Ahlquist \& Lindy Williams, How Statelessness, Citizenship, and Out-migration Contribute to Stratification Among Rural Elderly in the Highlands of Thailand, 99 SoCIAL ForCEs 323, 336 (2020).

${ }^{165}$ Amanda Flaim, Problems of Evidence, Evidence of Problems: Expanding Citizenship and Reproducing Statelessness Among Highlanders in Northern Thailand, in Citizenship IN QuesTion: Evidentiary BiRThrighT and Statelessness 147, 159-61 (Benjamin N. Lawrance \& Jacqueline Stevens eds., 2017).

166 Toyota, supra note 162 , at 118-19.

${ }^{167}$ Flaim, supra note 165 , at 161.

${ }^{168} \mathrm{Id}$. at 162 .

${ }^{169}$ Flaim, Ahlquist \& Williams, supra note 164 , at 337. 
Even for the highlanders who do possess the appropriate state-produced documentation, ethnographic accounts reveal that the documents themselves are often riddled with inconsistencies and subject to the unpredictable evaluation of state officials, that prevents them from evidencing citizenship. ${ }^{170}$ Given the constantly changing rules and policies and a proliferation of different categories of registration numbers and identity cards that distinguish between various kinds of non-citizens, errors in registration practices by state officials are not uncommon. Once produced, these errors can not only ensnare the individual in a bureaucratic maze of attempting to acquire the appropriate paperwork that evidences his claim to citizenship, but also highlight the fragility of these documents whose worth may always be challenged, rejected, or revoked. ${ }^{171}$ Not everyone has to bear the brunt of this hermeneutics of suspicion. The ethno-nationalist construction of the Thai state means the burden of enduring statelessness falls disproportionately on ethnic minorities like the highlanders who have long been subject to state discrimination. ${ }^{172}$ In addition to not being able to access the rights attached to citizenship, they are also at risk of being classified as unauthorized foreign workers and refugee populations from Burma, with whom they share ethnic and kinship ties, and labeled as illegal migrants. ${ }^{173}$

The legal configuration of territory in borderlands represents state attempts to pin down and delineate the ambiguous nature of belonging of the populations that inhabit and traverse these territories. In the process, inhabitants of these non-state spaces may be rendered outsiders in the name of state building, labor migration enforcement, and domestic security.

\section{Hardening Borders}

In order for the territorial border to identify and categorize people into insiders and outsiders with certainty, the border itself must give the illusion of being the stable eye in the storm of ever-changing population movements within and outside its limits. ${ }^{174}$ In bringing persons within the territorial fold and thereby the political authority of the state, the state engages in the production of collective identities that are developed and strengthened in opposition to external others. Since this exercise in building collective identity is often premised on a fictional unity among "insider" citizens, the presence of outsiders within poses a threat to the nation-state's territorial and political authority. In the words of Balibar, the attempt at consolidation is tinged with the ever-present danger that "outsiders or "nomadic subjects," in the broad sense, resist territorialization, remain located outside the normative "political space," in the land of (political) nowhere." 175 While Balibar's reference to nomadic subjects is intended to broadly refer to all internal others within the state's physical boundaries, his play on words highlights the different categories of people who pose a particular

\footnotetext{
${ }^{170}$ Janepicha Cheva-Isarakul, "Diagnosing” Statelessness and Everyday State Illegibility in Northern Thailand, 1 STATELESSNESS \& Citizenship Rev. 214, 216-27 (2019).

${ }^{171} \mathrm{Id}$. at $233-35$.

${ }^{172}$ Flaim, Ahlquist \& Williams, supra note 164, at 337, 361.

173 Toyota, supra note 162, at 128.

${ }^{174}$ See Étienne Balibar, We, The People of Europe?: Reflections on Transnational Citizenship 109 (2004) (characterizing the border as a "limit institution").

${ }^{175}$ Étienne Balibar, Europe as Borderland, at 4 (The Alexander von Humboldt Lecture in Human Geography, University of Nijmegen) (Nov. 10, 2004), available at http://gpm.ruhosting.nl/avh/Europe\%20as\% 20Borderland.pdf.
} 
challenge to the state's territorial concept of citizenship: groups that are excluded from its territorial imaginary and nomadic peoples. ${ }^{176}$

The bidoon (literally those "without nationality") of Kuwait are one group that has fallen victim to a "hyper-territorialised and hyper-localised" delineation of the boundaries of Kuwaiti membership. ${ }^{177}$ The 1959 Nationality Law based national membership on the concept of a settled population: entitlement to automatic citizenship was limited to individuals who could prove uninterrupted residence in the territory of the emirate since 1920 and their descendants (through the male line). However, the conception of territory in 1920 was not one of the "national" territory — since the borders of Kuwait were yet to be defined in 1920_ but the walls of the old town and surrounding oases. ${ }^{178}$ The initial beneficiaries of Kuwaiti citizenship were thus an eclectic mix of town dwellers - known as hadar in contrast to the badîu (bidoon) or the desert dwellers-that included the royal family and merchants, but also slaves and artisans. In addition, groups that had close networks with this sedentary population of town-dwellers through frequent presence in the territory, such as individuals living in the peripheral settlements, were included in this qualified citizenship. ${ }^{179}$

The inexperienced Committees of Nationality who were in charge of applying these nationality criteria to evaluate claims of citizenship had to rely mainly on oral testimonies of individuals and their community members rather than documentary evidence for proof of settlement. In the case of the bidoon who had applied for citizenship, the Committees were confronted with the dilemma that though the bidoon belonged to tribes that had settled within the "territorial limits" of the Kuwaiti desert, they could not claim to have lived within the town walls. As such, the work of the Committees that was premised on an urban concept of citizenship with a clear divide between the hadar and the badî was unable to account for the bidoons' claim to citizenship, a geographic and mental map that continues to influence the perception of the bidoon as internal others within Kuwait. ${ }^{180}$ Though the Kuwaiti government has made repeated promises over the years to ostensibly "resolve" the bidoon situation, its official agency tasked with this mandatethe Central System for the Remedy of the Situation of Illegal Residents established in 2010 - has persistently labeled the bidoon as "illegal residents," reportedly refusing to issue them with identity documents unless they confess to their "true" nationalities. ${ }^{181}$

The mental map of the modern nation-state in which groups such as the bidoon are trapped is often not only territorially, but also terrestrially, rigid: the borders are drawn on land rather than water, excluding the diverse ways of identity formation and belonging that are based on seascapes. ${ }^{182}$ Members of groups who inhabit the maritime interstices of

\footnotetext{
176 See Kesby, supra note 151, at 111 (using Balibar's theory to dissect states' closure of geographical borders to the Roma who are widely portrayed as a non-territorial nomadic people).

177 Claire Beaugrand, Statelessness \& Administrative Violence: Bidūns' Survival Strategies in Kuwait, MusLIM WORLD 228, 233 (2011).

${ }^{178} \mathrm{Id}$. at $232-33$.

${ }^{179} \mathrm{Id}$. at 233.

${ }^{180}$ Claire Beaugrand, Borders and Spatial Imaginaries in the Kuwaiti Identity, 23 GeOPOLITICS 544, 555-56 (2018)

${ }^{181}$ See Amnesty International, Kuwait: Mandate of Abusive Government Body in Charge of Stateless Bidun People Extended (Nov. 24, 2020), at https://www.amnesty.org/en/latest/news/2020/11/kuwait-mandate-of-abusive-government-body-in-charge-of-stateless-bidun-people-extended.

182 See Tom Gunnar Hoogervorst, Ethnicity and Aquatic Lifestyles: Exploring Southeast Asia's Past and Present Seascapes, 4 Water Hist. 245 (2012).
} 
these terra firma shaped boundaries find themselves without recognition in any of the territories claimed by nation-states. These groups, variously known as "sea gypsies" or "sea nomads," are often arbitrarily lumped together with "irregular migrants" notwithstanding their prolonged presence in maritime regions that straddle the borders of nation-states. ${ }^{183}$

The Bajau Laut of Malaysia are one such sea-faring nomadic population inhabiting an area that was traditionally part of the Sulu state and is now apportioned between Malaysia and the Philippines. Occupying the lowest rung in the ethnic hierarchy and exploited by other dominant ethnic groups, the boat-dwelling Bajau are considered a pariah people. ${ }^{184}$ Common to the various origin myths of the Bajau as a separate people is the commission of an act of sacrilege due to which they were cast out to sea and condemned to live the life of nomads as a people without religion and without a territorial home. ${ }^{185}$ This traditional Bajau nomadic existence and way of life underwent a significant transformation after World War II when a combination of market forces and government pressure led to the settlement of the majority of the Bajau and the adoption of a terrestrial lifestyle. ${ }^{186}$ However, a smaller percentage of the "sea Bajau" continue to have a semi-nomadic lifestyle, living in water-villages in peripheral and intertidal zones and even on house-boats plying the waters on Sabahs's eastern coast, at times all the way to the places of their ancestral origin in the Philippine waters. Most of them lack documentary proof of their residence in Malaysia and are considered as illegal residents by the Malaysian state. Denied access to the rights attendant upon citizenship in Malaysia and lacking recognition by any other country, they have been faced with a protracted situation of statelessness over successive generations. ${ }^{187}$

This rejection — cultural as well as political — of the Bajau Laut is characteristic of the symbolic rejection of peripatetic minority lifestyles by dominant sedentary majorities in modern nation-states. ${ }^{188}$ The Bajau Laut, like other nomadic groups inhabiting the state's peripheries, threaten both the state's political imaginary by rejecting the cultural model of citizenship associated with modernity and its security and immigration apparatus focused on policing movements within and beyond territorial boundaries. ${ }^{189}$

\section{Reinventing Borders}

Scholars writing on nationality and citizenship have remarked on the emergence of habitual (territorial) residence as a norm that is considered to constrain states' ability to deny individuals the right to citizenship. ${ }^{190}$ However, this emphasis on the coincidence of habitual residence and eligibility for citizenship understates the extent to which states are increasingly

${ }^{183}$ Greg Acciaioli, Helen Brunt \& Julian Clifton, Foreigners Everywhere, Nationals Nowhere: Exclusion, Irregularity, and Invisibility of Stateless Bajau Laut in Eastern Sabah, Malaysia, 15 J. Immigrant \& Refugee STUD. 232, 233 (2017).

${ }^{184}$ Carol Warren, Consciousness in Social Transformation: The Bajau Laut of East Malaysia, 5 Dialectical Anthropology 227, 228 (1980).

${ }^{185}$ Clifford Sather, Commodity Trade, Gift Exchange, and the History of Maritime Nomadism in Southeastern Sabah, 6 Nomadic Peoples 20, 36 (2002).

${ }^{186}$ Julian Clifton, Greg Acciaioli, Helen Brunt, Wolfram Dressler, Michael Fabinyi \& Sarinda Singh, Statelessness and Conservation: Exploring the Implications of an International Governance Agenda, 19 TILBURG L. Rev. 81, 85 (2014).

${ }^{187}$ Acciaioli, Brunt \& Clifton, supra note 183, at 236-37.

${ }^{188}$ Sather, supra note 185 , at 35 .

${ }^{189}$ Acciaioli, Brunt \& Clifton, supra note 183, at 242-43.

${ }^{190}$ See Spiro, supra note 26, at 721-23. 
engaged in decoupling territorial presence from political membership when doing so serves their political interests. Most of the literature on this separation focuses on the "ladders" rather than the "chutes" - to borrow Ayelet Shachar's vivid metaphor —of access to political membership, that is, the ability of elites to buy their way into the citizenship of states with whom they share no historical, socio-cultural, or even residential ties. ${ }^{191}$ These investor citizenship, golden passport, or cash-for-passport programs as they are variously labeled, allow states to fast-track the citizenship of those who they perceive as creating value for the state by dispensing with the traditional criteria for political membership and in the absence of any evidence of affective ties to the nation, even as states close the doors to "unworthy" internal others, including long term residents. ${ }^{192}$

One such ingenious scheme that severs the connection between territory and citizenship is the creation of a class of "offshore citizens" by governments such as the UAE and Kuwait. ${ }^{193}$ Noora Lori's incisive ethnographic account of the arrangement between the UAE and the Union of Comoros, one of the world's smallest and poorest countries, paints a striking picture of this practice of off-shoring. As Lori discusses, the process whereby the UAE purchased Union of Comoros passports to turn its own resident minorities into stateless "citizens" of Comoros was a carefully orchestrated process by the UAE Ministry of Interior. Beginning in 2008, the Ministry launched a statelessness registration drive and issued stateless identity cards to stateless individuals and those with pending naturalization applications. Persons with a stateless ID card were then issued Comoros passports with the understanding that the foreign passports were a temporary documentation measure to "regularize" their legal residence as foreigners in the UAE pending the eventual grant of UAE citizenship. ${ }^{194}$

Through this outsourcing arrangement, long-term resident minorities in the UAE have been transformed into temporary residents, permanently at risk of deportation. However, since these "passports of convenience" do not entitle passport recipients to call on the Union of Comoros for diplomatic protection or to reside in Comoros, it is unclear where they could be deported if the UAE were minded to expel them. ${ }^{195}$ This risk may in fact never materialize given that the limbo status of offshore citizenship is not foreseen as a pathway to expulsion, but rather as a form of conditional inclusion. Counting putative citizens as temporarily resident foreigners meets the UAE's security objective of comprehensively documenting its minority population and its economic interest in being able to call upon its labor, while simultaneously postponing any resolution of the political contestation around who belongs to the body politic. ${ }^{196}$ At the same time, the artificial attribution of the citizenship of Comoros to this population allows the UAE to avoid having to explicit deny them Emirati citizenship and the formal statelessness that would ensue. ${ }^{197}$

191 See Shachar, supra note 149, at 242, 246.

192 See the discussion in Peter Spiro, Cash-for-Passports and the End of Citizenship, in DeBATING Transformations of National Citizenship 17 (Rainer Bauböck ed., 2018). These schemes have been criticized by, among others, the European Commission, which launched infringement proceedings against Malta and Cyprus, two of the states with investor citizenship schemes.

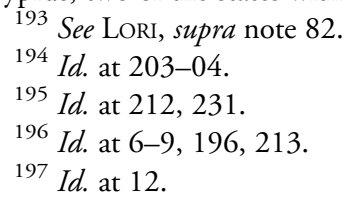


Off-shoring citizenship enables the UAE to perform the alchemy of converting would-be citizens to foreign residents without any modification of its territorial boundaries or any movement of population within and beyond these borders. A similar program introduced by Kuwait to outsource the bidoon to the Comoros was reportedly abandoned following international outcry, though a more cynical explanation is that carving a path for residence in the state would have undermined Kuwait's stance that the bidoon should return to the countries of their true nationality. ${ }^{198}$ Details of the current status of the UAE's scheme, which did not receive the same level of international visibility, are difficult to come by, but the latest reports suggest that Emirati holders of Comoros passports have found it either difficult or impossible to renew these passports, and in the latter case, have yet again found themselves without any identity documents. ${ }^{199}$

Scholars have noted that rather than being provoked by any real crisis, the UAE's statelessness problem was prompted by the UAE's "own attempts to exhaustively count and categorize all residents in the country without expanding the boundaries of the citizenry." ${ }^{200}$ As Part III will argue, the possibility that state identity regularization drives can create new forms of exclusion should inform international policymaking on statelessness.

\section{Statelessness as Administrative Practice}

As much as being a citizen of somewhere, anywhere, is a matter of meeting the criteria for citizenship, fulfilling these eligibility conditions counts for little if one lacks the means to prove it. The citizenship law of modern nation-states demands that individuals can give an account of their standing in the nation not in terms of identity or political membership, but in the form of evidence that the state considers legitimate. Moreover, the law assumes that this evidence is accessible to all putative citizens on equal terms. An individual who cannot furnish this officially sanctioned proof of his citizenship does not exist in the eyes of the nation; or rather, he exists, but not as a citizen, but as an alien. ${ }^{201}$ Since citizenship is constituted not merely through affective ties, performance, and ritual, but through documents, it is equally through documents - and their denial—-that statelessness can be constructed.

\section{Archival Erasure}

Can personal identity be obliterated through the destruction of an archive? Prior to the advent of documentation practices of state legibility, this could have been dismissed as a theoretical question with little impact on the identity and everyday life of a member in the political community. In the context of the modern nation-state, identity documentation has become a form of "administrative ordering" with both emancipatory and regressive consequences: identity documents are both vital for the welfare state to provide and expand access to social services as well as an instrument of surveillance and control for the state to "discipline

\footnotetext{
${ }^{198}$ Zahra Albarazi \& Yoana Kuzmova, Trafficking in (Non)-Citizenship in Kuwait and the UAE, in RoUTLEDGE Handbook of Citizenship in the Middle East and North Africa 349, 357 (Roel Meijer, James N. Sater \& Zahra R. Babar eds., 2020).

${ }^{199}$ Amnesty International, The State of the World's Human Rights 378 (2021), available at https://www. amnesty.org/en/wp-content/uploads/2021/06/English.pdf.

${ }^{200}$ LORI, supra note 82 , at 37.

201 See Daniel Kanstroom, Afterword, in Citizenship In Question, supra note 165, at 241-42.
} 
and punish" subjects. ${ }^{202}$ Official recognition of one's legal status through documents such as birth certificates, identity cards, and passports can empower individuals and collectives to assert claims against the state or against other members of the political community. ${ }^{203}$ At the same time, through providing the criteria for state legibility, documents can also be used to exclude, create, manipulate, and obscure identities, molding them to serve the different purposes of the state and in the process even shaping how individuals perceive themselves. ${ }^{204}$

The consequences of making a population visible through identity documentation is that one's membership in the state can be worth little more than the paper that it is written on. The case of "the erased" in Slovenia mentioned previously is a particularly chilling instance of the state's ability to transform community members into foreigners through paperwork, and with little in the way of warning. ${ }^{205}$ Many of the erased had failed to apply for citizenship in the sixmonth window for submitting applications either because they were given inaccurate information on the documents they would need to supply, or because they had practical concerns relating to inheritance and retirement in their countries of origin. Even more importantly, they were under the illusion that they would continue to retain their social rights as permanent residents with long term ties to Slovenia. ${ }^{206}$ The erasure of their records and loss of rights thus came as a shock: residents were asked to appear in person before official authorities and the documents pertaining to their residence were either confiscated or destroyed. ${ }^{207}$

Equally poignant is the case of "non-citizens" in Latvia and Estonia, whose identity was not erased, but rather reconfigured through documentation. While this status gives Latvian noncitizens a range of rights and privileges beyond stateless persons - for example, a special passport guaranteeing them the right of return, the right of residence, and the right to diplomatic protection - they have restricted political rights and are prohibited from occupying certain official positions. ${ }^{208}$ The lack of international pressure to clarify the international law status of Latvian non-citizens has received a boost with the 2005 Latvian Constitutional Court ruling that non-citizens cannot be classified as either stateless persons or as citizens, but occupy a sui generis status that should not be considered akin to Latvian citizenship. ${ }^{209}$

Much worse, from the point of view of access to state protection and rights, is the case of individuals registered as "nationality unknown" in the Netherlands. A designation applied to thousands of persons in the Dutch civil registration records, ${ }^{210}$ "nationality unknown" is

${ }^{202}$ See Wendy Hunter \& Robert Brill, "Documents, Please": Advances in Social Protection and Birth Certification in the Developing World, 68 World Pol. 191, 202 (2016); Jane Caplan \& John Torpey, Introduction, in DOCUMENTING INDIVIDUAL IDENTITY, supra note 12, at 1, 5.

${ }^{203}$ Caplan \& Torpey, Introduction, supra note 202, at 6.

${ }^{204}$ See Timothy Longman, Identity Cards, Ethnic Self-Perception, and Genocide in Rwanda, in DocumENTING INDIVIDUAL IDENTITY, supra note 12, at 345, 346-47 (on the relationship between colonial Belgian documentation practices and construction of ethnic identity in Rwanda and its eventual role in the Rwandan genocide).

205 See text at note 133 supra.

${ }^{206}$ Jelka Zorn, From Erased and Excluded to Active Participants in Slovenia, in Statelessness And the BenEFITS of Citizenship: A Comparative Study 50, 52 (Brad K. Blitz \& Maureen Lynch eds., 2009).

${ }^{207}$ Brad K. Blitz, Statelessness and the Social (De)Construction of Citizenship: Political Restructuring and Ethnic Discrimination in Slovenia, 5 J. HuM. RTs. 453, 462-63 (2006).

${ }^{208}$ Krūma, supra note 86 , at 9.

${ }^{209}$ Constitutional Court Case 2004-15-0106, Official Gazette No. 40, Mar. 9, 2005.

${ }^{210}$ Available at https://index.statelessness.eu/country/netherlands. 
premised on the individual's inability to prove a negative, namely, they do not hold any nationality. Unlike the category of statelessness, which would provide a pathway to citizenship in the Netherlands, "nationality unknown" leaves the individual in limbo, subject to detention and without any prospect of acquiring Dutch nationality. ${ }^{211}$ This practice was the subject of a petition before the UN Human Rights Committee (HRC) filed by a child born in the Netherlands to a Chinese mother who had been trafficked to the Netherlands as a minor and classified as an "illegal alien." 212 Since the mother was unable to acquire Chinese citizenship due to lack of birth registration in China and was also unable to conclusively prove that her son did not have any other nationality, the Dutch authorities refused to change his status from "nationality unknown" to "stateless," thus excluding him from the international protections applicable to stateless children. ${ }^{213}$ Mother and son were compelled to live in a center for unsuccessful asylum applicants and under constant risk of being deported. ${ }^{214}$ The HRC held that in depriving the petitioner of his right as a minor to acquire a nationality, the Netherlands had violated his right to a nationality under Article 24(3) of the International Covenant on Civil and Political Rights (ICCPR). In addition, the Netherlands had an obligation under the Statelessness Convention to " "determine whether a child would otherwise be stateless as soon as possible so as not to prolong a child's status of undetermined nationality."'215

The HRC decision signals a significant international victory for resolving cases of childhood statelessness in the Netherlands, in that it marks the beginning of a series of steps that would have to be undertaken in order to eventually acquire Dutch nationality. It was made possible by over a decade of strategic litigation by international and local NGOs and experts (including the Open Society Justice Initiative, which has actively pursued cases of statelessness before regional human rights mechanisms) coupled with an administrative court decision and a report by the Dutch Advisory Committee on Migration Affairs reprimanding the Dutch government for its failure to establish a stateless determination procedure. ${ }^{216}$ As Part III will argue, strategic litigation efforts that combine domestic and international expertise to mobilize a range of legal actors may provide one avenue to counter statelessness creep.

\section{Paper Non-citizens}

While administrative erasure is a clinically efficient way for a state to simply "disappear" various citizens from its books, a more insidious way to turn citizens into stateless persons is through "paper-izing" informal identity and the criteria for belonging. Documents such as ID

${ }^{211}$ UN Hum. Rts. Comm., Views Adopted by the Committee Under Article 5 (4) of the Optional Protocol, Concerning Communication No. 2918/2016, para. 2.4, Comm. No. 2918/2016, CCPR/C/130/D/2918/2016 (Jan. 20, 2021).

${ }^{212} I d$., paras. 2.1-2.2.

${ }^{213} I d$., para. 8.5

${ }^{214} I d$., para. 2.9.

${ }^{215} \mathrm{Id}$., paras. 8.3, 8.5.

${ }^{216}$ See Laura Bingham \& Jelle Klass, $A$ Victory for Human Rights in Zhao v. the Netherlands (the "Denny Case"): Nationality from Birth, Without Exceptions, EUI Global Citizenship Observatory (Jan. 19, 2021), at https:// globalcit.eu/a-victory-for-human-rights-in-zhao-v-the-netherlands-the-denny-case-nationality-from-birth-without-exceptions. 
cards and passports capture "the citizen himself as an effect of his 'mise en carte," 217 in the process thwarting or rendering obsolete previously important sources of recognition and identity. ${ }^{218}$ The state's supreme authority to evaluate and enforce identities through the official truths embodied in its documents authoritatively forecloses the possibility of officially unrecognized identities, including those that may challenge the falsehoods that are sanctified through officialdom. ${ }^{219}$ These documentary errors and inconsistencies are not always an outcome of a weakly bureaucratic state, but are at times an actively produced form of marginality in service of the state's political purposes. ${ }^{220}$ Citizenship that emerges through the law, its institutions, and forensic documentation-so-called administrative citizenship-can be a highly regulated and exclusionary institution that renders stateless already marginalized groups in society. 221

One of the most ambitious attempts at the "weaponization of documentary citizenship" is the effort to enumerate and comprehensively document the population of the Indian state of Assam through the implementation of a National Register of Citizens (NRC). ${ }^{222}$ The NRC has a long and tortured history in Indian politics, buffeted by waves of migration across the border between India and Bangladesh, leading to local Assamese anxieties about the influx of "illegal" Bangladeshi immigrants into the state across the porous border between the two countries. ${ }^{223}$ The NRC process that commenced in 2015 is intended to update the 1951 NRC, which was set up as a population enumeration exercise following the first national census of independent India. Based on the Citizenship Act, 1955 and The Citizenship (Registration of Citizens and Issue of National Identity Cards) Rules, 2003, it is ostensibly a highly legalistic exercise to identify Indian citizens and weed out "illegal immigrants," defined as those who can prove that they or their ancestors entered Assam before March 24, 1971, the eve of Bangladesh's declaration of independence from Pakistan. This proof consists of being able to furnish "legacy data": individuals can either submit documents evidencing that their names were included in the $1951 \mathrm{NRC}$ or on the electoral rolls before March 24,1971 . In addition, they can submit documentary proof, such as birth certificates or bank documents, of their family links to parents and ancestors who are included in the legacy data. 224

The requirement to provide documentary proof of residence stretching back several decades ignores the reality of documentation practices in a country like India, where a

${ }^{217}$ Jane Caplan, Illegibility: Reading and Insecurity in History, Law and Government, 68 Hist. WorksHOP J. 99, 103 (2009).

${ }^{218}$ Id.

${ }^{219}$ Caplan, supra note 217, at 104.

${ }^{220} \mathrm{Id}$.

${ }^{221}$ Kamal Sadiq, Limits of Legal Citizenship: Narratives from South and Southeast Asia, in STATELESSNESS AND THE BenefiTs of Citizenship, supra note 206, at 165-66. In their recent article, Michelle Foster and Jade Roberts also discuss the phenomenon of "documentary citizenship" and its politicization by the state to enact exclusion from within in the context of the NRC exercise in India. See Foster \& Roberts, supra note 6, at 228.

${ }^{222}$ Sahana Ghosh \& Radhika Moral, The Slipperiness of Documents: Notes from India's Eastern Borderlands (2020), at https://www.law.ox.ac.uk/research-subject-groups/centre-criminology/centreborder-criminologies/ blog/2020/02/slipperiness.

${ }_{223}$ See Talha Abdul Rahman, Identifying the "Outsider": An Assessment of Foreigner Tribunals in the Indian State of Assam, 2 Statelessness \& Citizenship Rev. 112, 113-18 (2020).

${ }^{224}$ See Praveen Donthi, How Assam's Supreme Court-mandated NRC Project Is Targeting and Detaining Bengali Muslims, Breaking Families, Caravan (July 1, 2018). 
significant percentage of the population lives its life bereft of any state-produced identity and where it is relatively easy to obtain fraudulent "official" documents to serve particular purposes. ${ }^{25}$ Indeed, many minority families that returned to Assam after the guarantee of safe passage under the 1950 Nehru-Liaquat Agreement did so only after the 1951 census and NRC exercise - that is said to have been carried out in less than a month-was completed. ${ }^{226}$ Thus, not only does the emphasis on inclusion in the 1951 NRC exclude various individuals who had been unable to register at the time, but given the geography of Assam where property and documents are regularly lost to natural disasters such as floods and land erosion, any paperwork paints at best a partial snapshot of the population. In addition, several classes of people in Assam, such as local Indigenous communities never saw the need to acquire documents that were considered an alien, colonial, process and others, such as women who were married as minors and transgender persons, would find it nearly impossible to prove documentary links to biological family members who qualify as citizens. ${ }^{227}$

It is not only those who lack the documentary proof required by the NRC exercise that have found themselves excluded from the final register, but also those who possess the right documents, but have the misfortune of having them recorded incorrectly. Since the transcribing, recording, and translation of the documents was done manually, modeling from previous error rates in the processing of such data in India reveals that around 5 percent of those with correct documents could have been excluded from citizenship due to something as minor as a spelling error. ${ }^{228}$

The NRC was published in August 2019 and the 1.9 million residents who were excluded from the register and classified as " $\mathrm{D}$ " or "doubtful" Voters, were given 120 days to appear before "Foreigners Tribunals," quasi-judicial bodies tasked with determining whether they are Indian nationals or illegal migrants who could be detained and subject to expulsion. ${ }^{229}$ Several of those labeled as illegal migrants challenged the NRC process arguing that the authorities had in fact never attempted to verify their status or that they had been the victims of fraud by those who wanted to lay claim to their property. ${ }^{230}$ The proceedings themselves were widely criticized as lacking independent and well-qualified judicial officers and procedural safeguards. ${ }^{231}$ Not only was the burden of proof placed on the supposed illegal immigrant to establish their right to citizenship, but any inconsistencies or errors in documents or testimonies were treated with suspicion, leading to persons being declared "foreigners" and placed in detention centers. ${ }^{232}$

225 See Kamal Sadiq, Paper Citizens: How Illegal Immigrants Acquire Citizenship in Developing Countries 26-28 (2008).

${ }^{226}$ Rahman, supra note 223, at 115.

${ }^{227}$ Ditilekha Sharma, Determination of Citizenship Through Lineage in the Assam NRC is Inherently Exclusionary, 54 ECON. \& POl. WeEkly (2019).

${ }^{228}$ Ghosh \& Moral, supra note 222.

${ }^{229}$ Rahman, supra note 223, at 123.

${ }^{230}$ Malini Sur, In the Name of Indian Citizenship? Criminalizing Statelessness at the India-Bangladesh Border, U. OXFord FACUlTy LAW Blog (2020), at https:/www.law.ox.ac.uk/research-subject-groups/centre-criminology/ centreborder-criminologies/blog/2020/02/name-indian.

${ }^{231}$ Rahman, supra note 223, at 128-36.

${ }^{232}$ Arijit Sen \& Leah Verghese, Weaponising Citizenship in India, U. OxFord Faculty Law Blog (2020), at https://www.law.ox.ac.uk/research-subject-groups/centre-criminology/centreborder-criminologies/blog/2020/ 02/weaponising. 
India is not the only country that has seen the production of statelessness as a consequence of a national effort at population enumeration and categorization. As scholars have noted, statelessness can be the intended as well as unintended result of state identity regularization drives, that are increasingly being undertaken by states also following sustained international pressure from agencies such as the United Nations and the World Bank that have promoted identity documents, including digital IDs, as a tool for social inclusion. ${ }^{233}$ In some cases, however, the rollout of these identification programs have been plagued with logistical and technical failures, resulting in the exclusion of already marginalized groups in society such as women or the elderly as in the case of Uganda. ${ }^{234}$ More troubling, however, for the purposes of this Article has been the deliberate effort by states to exclude minorities from these registration processes, as in the case of the Haitian migrants and Dominicans of Haitian descent mentioned previously. Recent scholarship has sought to draw a link between the advocacy of legal identity documents by international actors and the measures taken by the Dominican Republic to exclude these populations from accessing this documentation, rendering their entitlement to the rights of citizenship even more precarious. ${ }^{235}$ As states undertake efforts to consolidate and strengthen their processes for identity management, individuals and groups who do not fall within the state's political imaginary may either be systematically left out of documentation processes, or assigned the label of "stateless" persons, thus fixing what was previously a fluid and malleable identity. ${ }^{236}$ This is an issue to which Part III returns with a cautionary message for international policy actors.

\section{Bureaucratic Statelessness}

Even for individuals who are entitled to claim citizenship in a state, access to citizenship is not merely a matter of formal laws or policy; rather, conferral of citizenship involves the conferral of belief by officials tasked with administering these laws. The processing and evaluation of citizenship claims is thus contingent not only on the strength of the evidence that the claimant can provide, but also on the individual judgment and discretion exercised by the official in charge. This valuation will not always produce citizenship but may reinforce or prolong statelessness. ${ }^{237}$

Recent legal developments at the international and regional human rights bodies display greater awareness and heightened scrutiny of the role of bureaucracy in the creation of statelessness. ${ }^{238}$ The case of the Nubians of Kenya before the African Commission on Human and

233 See, e.g., World Bank, Inclusive and Trusted Digital ID Can Unlock Opportunities for the World's Most Vulnerable (Aug. 14, 2019), at https://www.worldbank.org/en/news/immersive-story/2019/08/14/inclusiveand-trusted-digital-id-can-unlock-opportunities-for-the-worlds-most-vulnerable.

${ }^{234}$ Center for Human Rights and Global Justice, Initiative for Social and Economic Rights, \& Unwanted Witness, Chased Away and Left to Die: How a National Security Approach to Uganda's National Digital ID Has Led to Wholesale Exclusion of Women and Older Persons (2021), available at https://chrgj.org/wp-content/ uploads/2021/06/CHRGJ-Report-Chased-Away-and-Left-to-Die.pdf.

235 See Eva Hayes de Kalaf, Legal Identity, Race, and Belonging in the Dominican Republic: From Citizen to Foreigner (2021).

${ }^{236}$ LORI, supra note 82 , at 201-03.

237 See Flaim, supra note 165, at 148.

${ }^{238}$ See, e.g., Committee on Economic, Social \& Cultural Rights, Concluding Observations: Macedonia, para. 32, UN Doc. E/C.12/MKD/CO/1 (Jan. 15, 2008) (asking Macedonia to remove administrative obstacles to the acquisition of citizenship by the Roma); CERD, Concluding Observations: Croatia, para. 17, UN Doc. 
Peoples' Rights illustrates the uphill battle faced by communities and groups seeking to prove evidentiary statelessness based on everyday bureaucratic state practices. ${ }^{239}$ Described as a "subject race turned ethnic stranger," the Nubians were conscripted from Egypt and Sudan into the British colonial armed forces and migrated to Kenya as part of the British colonization effort in East Africa. Having been categorized as "detribalized natives" who were subject to native local laws during the colonial era, the Nubians found themselves in a politically challenging and legally uncertain post-independence environment due to their previous association with the colonial administration. ${ }^{240}$ The Nubians were in principle entitled to claim Kenyan nationality at the time of Kenya's independence in 1963 on the basis of the jus sanguinis principle. However, in practice, many of them were excluded from obtaining citizenship since Kenya did not include the Nubians amongst one of the forty-two official ethnic groups and few Nubians had documentary proof that would allow them to establish citizenship by descent from individuals living in Kenya over two generations. ${ }^{241}$

Given the difficulties in establishing their citizenship based on descent, the Nubians have been relegated to seeking citizenship status through naturalization and registration. These processes lack detailed procedural safeguards and rules to orient administrative decision making, resulting in significant discretion being exercised by administrative officials. ${ }^{242}$ Perceived by many Kenyans, including Kenyan officials, as "foreigners" lacking a recognized homeland and land tenure in the manner of the official tribes, the Nubians have been subjected to additional vetting procedures to obtain important documents such as national ID cards, which are amongst the most important official markers of Kenyan citizenship. ${ }^{243}$ The vetting procedures have been criticized as highly discriminatory and prone to corruption, with the Muslim identity of the Nubians being treated as a ground for suspicion and demands for additional documentary proof of ancestral ties to Kenya, such as birth certificates of parents and grandparents. ${ }^{244}$ Commentators have noted that since these acts of discrimination that produce evidentiary statelessness do not stem from any identifiable law or official policy but are rather the result of fragmented decisions made by state agents on an individual basis, they are harder to prove and challenge before courts and other bodies. ${ }^{245}$

The African Commission's decision in the Nubian Community in Kenya is one of the rare examples where these claims were in fact successful, though only after significant advocacy and a string of failed efforts at the domestic level. The Commission held that the exercise of administrative decision making in the issuance of identity documents was not only

CERD/C/HRV/CO/8 (Mar. 24, 2009) (asking Croatia to remove administrative barriers and assist persons such as those of Roma, Serb, or Bosniak origin, who have limited access to mandatory documentation); CERD, Concluding Observations on the Thirteenth to Fifteenth Periodic Reports of Suriname, para. 20, UN Doc. CERD/C/SUR/CO/13-15 (Aug. 28, 2015) (calling on Suriname to remove administrative barriers and discriminatory practices to prevent statelessness, particularly in relation to birth registration).

239 The Nubian Community in Kenya v. The Republic of Kenya, Comm. 317/2006, 17th Extraordinary Sess., Feb. 19-28, 2015.

${ }^{240}$ Samantha Balaton-Chrimes, Indigeneity and Kenya's Nubians: Seeking Equality in Difference or Sameness?, 51 J. Mod. Afr. Stud. 331, 332, 338 (2013).

${ }^{241}$ Abraham Korir Sing'Oei, Promoting Citizenship in Kenya: The Nubian Case, in STATElessness ANd the Benefits of Citizenship: A Comparative Study, supra note 206, at 37, 38-39.

242 Id. at 39.

243 Balaton-Chrimes, supra note 240, at 339-40.

244 Wendy Hunter, Undocumented Nationals: Between Statelessness and Citizenship 48-49 (2019).

245 Id. at 50. 
arbitrary and burdensome for the Nubians, but that the overt discrimination against the Nubians on the basis of their ethnic and religious identity was a clear violation of their dignity and the right to equality and non-discrimination under the African Charter. ${ }^{246}$ In addition, these discriminatory practices, procedural hurdles, and delays in the acquisition of identity documents prevented the Nubians from exercising the rights associated with citizenship and rendered them effectively stateless, violating the right to recognition of legal status guaranteed under Article 5 of the Charter. ${ }^{247}$

While the decision has led to a few concrete changes at the domestic level, including the presence of Nubians on the vetting committees and acceleration in birth registrations and issuance of identity documents, administrative discretion in the process has been retained. The applicant still bears the burden of proof to establish citizenship before the vetting committees, which operate with few procedural rules and without any possibility of an appeal against their decisions. ${ }^{248}$ Neither is the situation of bureaucratic statelessness experienced by the Nubians entirely exceptional, whether in Kenya or beyond. In the African context, scholars have argued that notwithstanding ostensibly neutral citizenship laws, various groups associated with the colonial legacy or living in border regions have had their citizenship status challenged and been required to prove their entitlement to nationality. ${ }^{249}$ A less well-known example from Kenya itself are the Makonde, descendants of migrant farm workers who were brought to Kenya from Mozambique beginning in the 1930s to work on sisal plantations. While they were not automatically entitled to Kenyan citizenship at the time of independence due to the restrictive requirements of jus sanguinis, they would have been eligible for citizenship through registration, a procedure that most of them failed to go through due to lack of information, cost, or the assumption that they will be returned to Mozambique. ${ }^{250}$ After decades of being denied or facing discrimination in the acquisition of birth certificates and identity documents, it is only after extensive lobbying that they obtained a directive for their naturalization and registration as Kenyan citizens in 2016, a move that was interpreted as politically expedient for the government given the impending national elections. ${ }^{251}$ As recently as last year, the Kenyan biometric ID scheme that aims to provide every Kenyan with a unique identification number was accused of "digitizing discrimination" by systematically making it more difficult for minorities such as Nubians and Kenyan Somalians to apply for a digital ID. ${ }^{252}$

\section{Responding to Statelessness}

While, as Part II has described, international and regional actors have begun to take steps to combat state intentionality in the creation of statelessness, these efforts have been geared

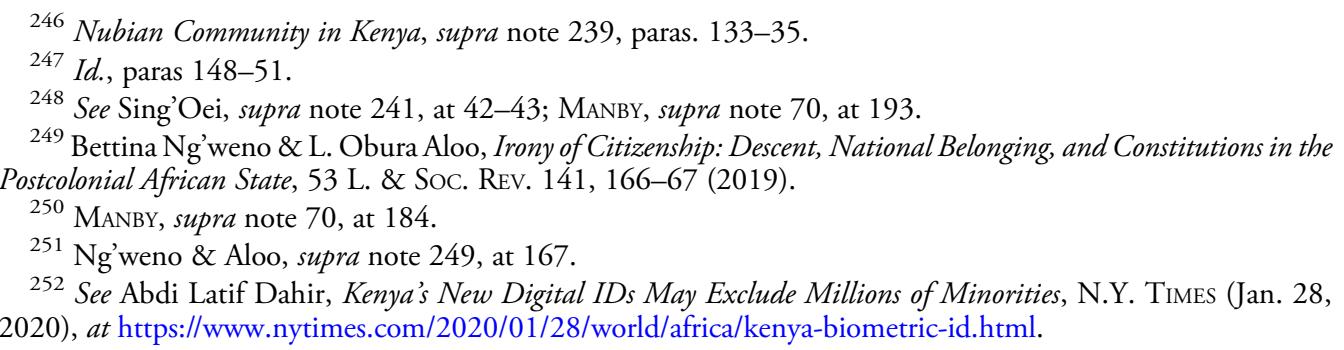


toward the minutiae of combating country-specific cases of statelessness. What they have failed to appreciate is that an exclusionary tactic or method that might seem peculiar to the circumstances of a certain minority group, in the context of a particular state, is in fact an instance of the larger phenomenon of statelessness as statecraft. This creeping form of statelessness does not come breathing fire and brimstone, but rather takes the form of manipulating the criteria for inclusion in the political constituency based on seemingly impartial criteria underpinning citizenship entitlement. ${ }^{253}$ These ostensibly neutral criteria become difficult to evaluate or challenge given the fact of citizenship as an inherently exclusionary institution that simultaneously claims to be theoretically open to all but is nonetheless premised on an act of boundary-drawing between community members and outsiders. ${ }^{254}$

The Article does not claim to provide a comprehensive answer to the larger question of "who has a claim to be included in a democratic polity," an issue that has confounded not only international lawyers, but also political theorists and philosophers. ${ }^{255}$ Rather, it argues that state prerogative to exclude individuals from political membership and in the process render them stateless, can be subject to fundamental international law norms such as non-discrimination. A prima facie discrimination claim should arise in situations of statelessness involving the denial of citizenship rights to a class of individuals notwithstanding the existence of a close connection with the state such that they are not only affected by its laws and policies, but also depend on it for their well-being and autonomy. ${ }^{256}$ In principle, this would include claims based on "birthright citizenship," that is citizenship through descent or through birth on the territory, but also on the fact of habitual or prolonged residence on the territory of a state, ${ }^{257}$ an element that characterizes many of the situations discussed in Part II. The salience of habitual residence as evidence of a substantial and real connection between the individual and the state has already been recognized in instruments on state succession where it functions as the default basis for attribution of citizenship. ${ }^{258}$

Even if the individual is able to demonstrate this close connection with the putative state of nationality, they would still face an uphill battle establishing that the exclusion from citizenship violates the prohibition of non-discrimination such that international intervention is appropriate. As the examples in Part II highlight, while current state practices of sorting populations into boxes of citizens and stateless others exhibit continuities with traditional discriminatory modes of exclusion, rather than using "suspect categories of discrimination" such as race, religion, or ethnic origin that are explicitly mentioned in various international

${ }^{253}$ Lori, supra note 110 , at 132.

254 See Linda Bosniak, The Citizen and the Alien: Dilemmas of Contemporary Membership 102 (2006) (noting how "citizenship talk ... trades in both universalism and particularism").

${ }^{255}$ For a masterful recent attempt to develop principles that respond to this question, see Rainer Bauböck, Democratic Inclusion: A Pluralist Theory of Citizenship, in Democratic Inclusion: Rainer BaubÖck IN Dialogue 3 (2017).

${ }^{256}$ This is an amalgam of principles for democratic inclusion proposed by Rainer Bauböck. These principles are both complex and contested in citizenship theory (see Democratic InClusion: Rainer BauböcK IN Dialogue, supra note 255). This Article does not propose to enter into these debates or develop a new political theory of citizenship. Rather, these principles are put forward as intuitively appealing grounds for inclusion that moreover resemble international law's emphasis on a genuine and effective link for the attribution of nationality.

257 See Bauböck, supra note 255, at 66.

${ }^{258}$ Council of Europe Convention on the Avoidance of Statelessness in Relation to State Succession, supra note 56, Art. 5; ILC Draft Articles, supra note 57, Art. 5. 
and regional human rights instruments, states rely on the purportedly unbiased and stable criteria of geography, time, and documentation, to enact and implement statelessness. ${ }^{259}$

Theoretically, these legal tools are equally applicable to any individual seeking entry into the gates of citizenship. Quantitative measures such as time that are perceived as scientifically objective have a special resonance in liberal polities with a commitment to equal treatment of similarly situated individuals. As Cohen recounts, "[c]locks and calendars exhibit no independent bias." 260 This makes chronological time ideally suited as a proxy to avoid the arbitrariness and subjectivity associated with qualitative criteria for political membership such as those that measure affective ties, loyalty, or cultural assimilation. However, as this Article has shown, temporal rules and standards are not always impartial or egalitarian. In practice, states apply them selectively to achieve the same objectives as measures that would immediately invite international oversight or condemnation. ${ }^{261}$

The same is true of states' manipulation of legal geography and documentation practices, which can render citizenship indeterminate through denial and revocation of nationality but also through suspending individuals in the liminal space between citizenship and statelessness. ${ }^{262}$ Through the miracle of the written word, documents such as identity cards can ascribe a status that far from substantiating the truth, "sometimes plunge[s] their referents into a reality that is incommensurable with their sense of self," 263 by transforming citizens into stateless persons. State machinery and techniques for operationalizing citizenship that are facially procedural can in fact embody substantive value judgments on who has to contend with the hermeneutics of suspicion when accessing and adducing documentary proof of membership. For some more than others, the road to citizenship is paved with bureaucratic hurdles and the "legalized illegality" of routine exclusion by official agencies. ${ }^{264}$

This Article has a simple_albeit ambitious_-prescriptive message: instead of continuing to rely on ad hoc and piecemeal legal and advocacy efforts, international law needs to develop a legal roadmap — one that not only equals but surpasses the state's creativity — to avoid, prevent, and respond to statelessness. This roadmap must be responsive to sophisticated legal concepts, interpretations, and practices that give the state the leeway to disenfranchise and exclude without running up directly against international law norms that constrain statelessness. It thus needs to recognize and challenge the ways in which states exclude, not only or even predominantly through explicitly prohibited grounds of discrimination, but through tampering with the standard universal criteria for political inclusion. And it needs to be sufficiently agile to keep pace with the shifting landscape of statelessness production that is constantly shaped and reshaped by the state's legal imagination. ${ }^{265}$

\footnotetext{
259 See Ayelet Shachar, The Multiple Sites of Justice: A Reply, in THE SHIFTING Border, supra note 110, at 242 (making a similar argument in the context of migration control through the legal device of "shifting borders").

${ }^{260}$ CoHEN, supra note 78 , at 11 .

${ }^{261}$ See id.

262 Jacqueline Stevens, Introduction, in CiTIZENSHIP IN QUeSTION, supra note 165, at 1, 3-4.

${ }^{263}$ Barbara Yngvesson \& Susan Bibler Coutin, Backed by Papers: Undoing Persons, Histories, and Return, 33 AM. ETHNOLOGIST 177, 184 (2006).

${ }^{264}$ Jacqueline Bhabha, The Politics of Evidence: Roma Citizenship Deficits in Europe, in CITIZENSHIP IN QuESTION, supra note 165, at 43, 45-46.

265 See id.
} 
Much like the multiple sites at which statelessness is produced, this roadmap too will need concerted legal, institutional, and advocacy efforts by a range of international, regional, and local actors. This Part explores three such potential instruments rooted in international law doctrine, policies, and litigation strategies that may be pursued by actors who play different roles in international norm-building. These efforts, experimental as they are, emphasize a multi-actor collaborative process guided by ethical incrementalism which respects the complexity of the conditions for political belonging in societies. Legal and political measures to tackle the production of statelessness must not only be grounded in normative principles such as non-discrimination, but also in pragmatic considerations as to their real-world consequences and potential for backlash. An ethically incremental approach would allow for the development of new legal and policy tools over time through a process of continuous learning and feedback on the understanding that small steps carried out responsibly and effectively can lead to genuine social change.

\section{A. The Promise of Indirect Discrimination}

The prohibition of discrimination is one of the core guarantees enshrined in international as well as regional human rights treaties. Notwithstanding variations in language across different instruments, the prohibition is understood to encompass both "direct" and "indirect" discrimination, either expressly or through interpretation. ${ }^{266}$ While the dividing line between the two forms of discrimination is neither uniform nor always clear, in general, "direct discrimination" refers to deliberate or intentional unjustified differential treatment based on a suspect category, whereas the notion of indirect discrimination is concerned with seemingly neutral laws, policies, and practices that have a disproportionately adverse impact on a protected category. ${ }^{267}$ Prominent theorists of discrimination law argue that discrimination is a highly mutable and adaptable phenomenon, becoming even more elusive when under attack - in other words, precisely the kinds of scenarios outlined in this Article — and indirect discrimination norms are the law's way of "playing catch up" with its plasticity. ${ }^{268}$ Indeed, nearly all of the rare legally successful challenges to the production of statelessness - as in the case of the Kenyan Nubians, the Slovenian erased, and the Dominicans of Haitian descent - have relied in part on the prohibition on discrimination, albeit without clearly distinguishing between the direct and indirect forms, as one of the underlying rights violations. Given the promise that the law of indirect discrimination in particular holds for challenging exclusionary but facially neutrally state policies and techniques of the kind discussed in Part II, why has it not emerged as a ubiquitous instrument for courts and other human rights bodies to challenge statelessness?

Part of the problem lies in the nebulousness of indirect discrimination itself. As Victor Madrigal-Borloz, the UN Independent Expert on Protection against Violence and Discrimination Based on Sexual Orientation and Gender Identity has recently stated, "conceptualizations of indirect discrimination are largely absent from the doctrine and case law of United

${ }^{266}$ See, e.g., Biao v. Denmark, App. No. 38590/10, para. 114 (Eur. Ct. H.R. May 24, 2016) (interpreting the ECHR); Kambole v. United Republic of Tanzania, App. No. 018/2018, Judgment, paras. 69-72 (Afr. Ct. H.P.R. July 15, 2020) (interpreting the African Charter).

${ }^{267}$ See Hugh Collins \& Tarunabh Khaitan, Indirect Discrimination Law: Controversies and Critical Questions, in Foundations of Indirect Discrimination LaW 1, 2 (Hugh Collins \& Tarunabh Khaitan eds., 2018).

268 See Tarunabh Khaitan, Indirect Discrimination, in The Routledge Handbook of the Ethics of Discrimination 30 (Kasper Lippert-Rasmussen ed., 2017). 
Nations ("UN") human rights treaty bodies and special procedures."269 Another recent study analyzing the individual communications of the HRC giving effect to the prohibition of discrimination under Article 26 of the ICCPR argues that the HRC has paid lip-service to the notion, with its approach in concrete cases being far from even. The Committee's abstract pronouncement that distinctions between groups that are based on "objective and reasonable grounds" can be justified has led to contradictory outcomes in analogous fact situations. ${ }^{270}$

There are several possible explanations for this reluctance to engage deeply with the substance and implications of the doctrine of indirect discrimination by human rights bodies. Conceptually and normatively, it is contested why indirect discrimination constitutes a moral wrong in the first place. Theorists disagree, for instance, on whether direct and indirect discrimination share a common moral foundation, such as equal respect for persons, or if indirect discrimination does not wrong an individual in the same way but may nonetheless be prohibited on grounds of distributive justice so as to promote equality of opportunity and social welfare that takes into account the unfair distribution of benefits and opportunities for some groups of people. Other scholars suggest that indirect discrimination constitutes a distinct moral wrong because it compounds existing societal injustice. ${ }^{271}$ Still others suggest that rather than constituting an independent moral wrong, indirect discrimination should be viewed as a pragmatic instrument to achieve objectives pursued by the law of direct discrimination: it can smoke out pretextual discrimination, serve as evidence of discriminatory intent, and strengthen the effectiveness of norms prohibiting direct discrimination by also sanctioning policies and practices that are unconsciously or accidentally discriminatory. ${ }^{272}$ These normative differences as to what makes indirect discrimination wrongful may impact the law's conception of when it should be considered wrongful and whose perspective- the one of the alleged perpetrator or that of the alleged victim(s) - will be given weight. ${ }^{273}$

For advocates as well as the human rights institutions themselves, labeling something "indirect" rather than "direct" discrimination then poses a Catch-22. If indirect discrimination does not signal the same kind of "bad faith" on the part of the policymaker, as does its direct counterpart, then it may not imply the kind of blameworthiness that advocates want to call out and target. On the other hand, it is precisely because of the "softer" condemnation of state policy without the corresponding moral judgment that a ruling of indirect discrimination may be more palatable to states and reduce the potential for political backlash. This may be the case even though indirect discrimination highlights the ways in which exclusionary policies reflect and amplify, not just individual, but structural discrimination, and thus may necessitate transformational, institutional reform. ${ }^{274}$

${ }^{269}$ Victor Madrigal-Borloz, The Theory of Indirect Discrimination: Application to the Lived Realities of Lesbian, Gay, Bisexual, Trans, and Other Gender Diverse (LGBT) Persons, 34 HaRV. Hum. RTs. L.J. 295 (2021).

${ }^{270}$ Niels Petersen, The Implicit Taxonomy of the Equality Jurisprudence of the UN Human Rights Committee, 34 LEIDEN J. INT'L L. 421, 429-430 (2021).

271 See Deborah Hellman, Indirect Discrimination and the Duty to Avoid Compounding Injustice, in Foundations of INDiRect Discrimination Law, supra note 267, at 105, 105-06 (discussing disagreements between theorists as to the distinction between direct and indirect discrimination).

272 Collins and Khaitan, supra note 267, at 25-26.

273 See Gerald L. Neuman, Questions of Indirect Discrimination on the Basis of Religion, 34 HarV. HuM. RTS. L.J. 177, 180 (2021).

274 See Indirect Discrimination and Sexual Orientation and Gender Identity: October 2020 Workshop Proceedings, at 18-19 (Harvard Human Rights Program Research Working Paper Series). 
This dilemma is illustrated by the co-evolution of the doctrines of direct and indirect discrimination in the jurisprudence of the ECtHR. The court first formally recognized indirect discrimination in the form of disproportionately prejudicial impact on a protected group pursuant to a neutral policy in the case of D.H. and Others $v$. the Czech Republic, a case dealing with the disproportionate impact of a general educational rule on Roma children in the Czech Republic. The court ruled that prima facie evidence of this discrimination could be produced through statistical evidence showing disproportionate prejudicial impact on the protected group compared to a similarly situated group. It would nonetheless be open to the state to justify the indirect discrimination by demonstrating that the policy pursued a legitimate aim through measures that were both proportionate and necessary. ${ }^{275}$

While DH and Others could have been a turning point in the ECtHR's approach to discrimination, it has fallen short of that promise. For one, the court does not always distinguish between direct and indirect discrimination in its case law, making it difficult to trace the impact of the latter, in particular since there have been few pronouncements on indirect discrimination outside the context of education segregation. ${ }^{276}$ There is also a lack of meaningful precision in the standard for justified discrimination — what, for instance, is a legitimate aim? - which is further compounded by the margin of appreciation accorded to states in the application of the European Convention on Human Rights (ECHR). Scholars claim that even though the court requires "very weighty reasons" to justify differential treatment on protected grounds such as gender, race, and religion, this heightened protection is often diluted by the court's deference to states under the margin of appreciation. ${ }^{277}$

Even so, the court's embrace of indirect discrimination has invited a steady stream of objections from defendant states as well as individual judges of the ECtHR in their separate and dissenting opinions, a pressure that the court has withstood thus far, but for reasons that may not be entirely benign. ${ }^{278}$ In a fascinating study dissecting the court's racial discrimination jurisprudence, Barbara Havelková contrasts the court's willingness to infer structural prejudice from statistical evidence in indirect discrimination cases and its failure to infer racial motive in arguably more egregious cases of direct discrimination. Havelková queries whether this divergent approach is because "[f]inding structural bias can be more palatable than finding racist motives." 279 Seen in this light, rather than a progressive tool for furthering anti-discrimination norms, indirect discrimination appears to be a way for the court to avoid making uncomfortable pronouncements on racist bias. Indeed, as Havelková goes on to argue, "in several of the post- $D H$ discrimination cases, the Court did not merely not require a proof of intent, but seemed to reassure the defendant state that their finding of discrimination was not meant to imply the government had racist intentions." 280

275 D.H. v. The Czech Republic, 2007-IV Eur. Ct. H.R., para. 196.

276 See Mathias Möschel, The Strasbourg Court and Indirect Race Discrimination: Going Beyond the Education Domain, 80 Mod. L. Rev. 121, 124-125 (2017).

277 See Samantha Besson, Evolutions in Non-discrimination Law within the ECHR and the ESC Systems: It Takes Two to Tango in the Council of Europe, 60 AM. J. CoMP. L. 147, 167-71 (2012).

${ }^{278}$ See Barbara Havelková, Judicial Scepticism of Discrimination at the ECtHR, in FoundaTIONS OF INDIRECT DisCRimination LAW, supra note 267 , at 83,84 , 98-99.

${ }^{279} \mathrm{Id}$. at 98.

${ }^{280} \mathrm{Id}$. at 101. 
As these developments highlight, much conceptual excavation and doctrinal fine-tuning remains to be done for international and regional norms on indirect discrimination to realize their potential, in particular when it comes to challenging the state's prerogative on matters that relate to membership in the political community. What kinds of evidence would be needed to argue that ostensibly neutral policies such as demanding registration requirements that have served to disenfranchise Thai hill tribes or documentation drives that have led to the UAE's practice of off-shore citizenship for minority groups, constitute instances of prohibited discrimination? Would it be more strategic to deliberately frame challenges to manufactured statelessness as not implicating malign intentions, but rather state failure to pay sufficient attention to the prejudicial impact of its neutral policies on a protected group? Alternatively, would it be better to consciously blur the boundaries between direct and indirect discrimination by rethinking whether direct discrimination must always require deliberate intent to discriminate? In domestic legal systems, for example, jurisdictions such as Canada have chosen to abandon the distinction between the two categories of discrimination whereas those such as the UK treat the distinction as one of degree rather than kind, with proof of deliberate intent to discriminate not required for either form of discrimination. ${ }^{281}$

\section{B. Strategic Litigation as a Way Station}

As the examples of state-choreographed statelessness in Part II revealed, some of the partial successes in constraining statelessness practices in cases such as the Dioula ethnic community in Côte d'Ivoire and those "without nationality" in the Netherlands have come from actors bringing claims before regional human rights courts and bodies. Indeed, many would be classified as instances of "strategic litigation," where, in the words of one of its main proponents, the Open Society Justice Initiative (OSJI), the claimant pursues "legal action in a court that is consciously aimed at achieving rights-related changes in law, policy, practice, and/or public awareness above and beyond relief for the named plaintiff(s)."282

Transnational and international strategic litigation is a relatively recent phenomenon with its fair share of both supporters and detractors. For one, there are inherent challenges with identifying a "test case" for the purposes of strategic litigation efforts. Or as Adam Weiss, the managing director of European Roma Rights Centre puts it, "strategic litigation has a lot in common with the notion of "black swans"” and "[w] hat makes a case strategic can only be seen in retrospect." 283 There is always a risk that the lawyer(s) attempting to engage in the risk versus rewards exercise of the potentially beneficial outcome gets the calculation wrong, leading to an unfavorable outcome that ends up reversing, instead of accelerating, the campaign for legal reform. And even cases that result in victories might only incentivize states to come up with workarounds that avoid the precedent set by a negative ruling. ${ }^{284}$ Moreover, overreliance on one court as a site for demanding rights comes with its own problems and can increase the possibility of backlash from states and domestic non-state actors such as

${ }^{281}$ See Collins \& Khaitan, supra note 267, at 21-25 (discussing the distinction between the two categories of discrimination in a number of different jurisdictions).

${ }^{282}$ Open Society Justice Initiative, Strategic Litigation Impacts: Insights from Global Experience, at 25 (2018).

283 Adam Weiss, The Essence of Strategic Litigation, in Strategic Litigation: Begriff Und PraXis 27, 28 (Alexander Graser \& Christian Helmrich eds., 2019).

${ }^{284}$ See, e.g., Cathryn Costello, Strategic Litigation to Vindicate the Rights of Refugees and Migrants: Pyrrhic Perils and Painstaking Progress, in Legal Cases That Changed Ireland (Ivana Bacik \& Mary Rogan eds., 2016). 
conservative parties or lobby groups. ${ }^{285}$ And finally, there is the ever-present question of resources: even if lawyers could be confident of choosing wisely, not all of them have the institutional or financial capacity to pursue strategic litigation. It is not surprising to see studies highlighting that strategic litigation before supranational courts is dominated by a few players who tend to be larger well-funded organizations or smaller organizations that can partner with them. ${ }^{286}$

Notwithstanding these limitations within which strategic litigation operates, scholarship as well as practice, including in the context of statelessness, point to ways in which strategic litigation can act as "a pebble that paves the road for certain [rights-enhancing] changes."287 The earlier example of OSJI's successful claim before the African Commission on Human and People's Rights challenging Côte d'Ivoire's denial of nationality to members of the Dioula ethnic community is a good illustration of some of the elements that would need to be in place to maximize the chances of strategic litigation translating into positive legal change. The first is acute sensitivity to the political and social environment that is especially important for politically explosive issues such as citizenship. In the case of Côte d'Ivoire, as previously mentioned, President Ouattara's ascendency to political office meant that the shifting political winds were likely to favor the Commission's decision. Strategic litigators seeking to combat statelessness can, however, also play a part in preparing the ground so as to increase the likelihood of compliance with supranational decisions through mechanisms such as robust local civil society mobilization and bringing "preparatory" cases at the national level that feed into and reinforce the supranational ruling. ${ }^{288}$ Complementary rulings by progressive and independent domestic courts combined with legitimation through national human rights actors might help counter the perception of supranational meddling in sovereign matters related to the grant of nationality.

Equally important is what happens in the aftermath of a successful ruling, even when it falls on fertile political ground. The importance of strategic litigators actively engaging with implementation in the post-judgment phase has been borne out in the context of supranational courts, such as the ECtHR and the IACtHR. ${ }^{289}$ For example, research on the experience of litigating Chechen cases at the ECtHR has shown the crucial role played by NGOs in the post-litigation phase in actively lobbying the Committee of Ministers tasked with supervising the implementation of the court's judgments by submitting memoranda and creating networks with Council of Europe officials. ${ }^{290}$ In Côte d'Ivoire, following the Commission's decision on denial of nationality, OSJI worked closely with civil society actors to build local and

285 See, e.g., Daniel Thym, The End of Human Rights Dynamism? Judgments of the ECtHR on "Hot Returns" and Humanitarian Visas as a Focal Point of Contemporary European Asylum Law and Policy, 32 INT'L J. RefugEe L. 569 (2020) (analyzing the European courts' recent turn away from rights-enhancing judgments in the context of migration litigation in light of the changing political context and perceptions of their legitimacy).

286 See Heidi Nichols Haddad, The Hidden Hands of Justice: NGOs, Human Rights, and International COURTS 61-62, 104-05 (2018) (surveying the types of NGOs that typically engage in strategic litigation at the ECtHR and the IACtHR).

287 Open Society Justice Initiative, Strategic Litigation Impacts: Roma School Desegregation, at 72 (2016) (quoting a Czech Ministry of Justice official on the impact of the ECtHR's ruling in DH on the Czech legal landscape).

288 See Moritz Baumgärtel, Demanding Rights: Europe's Supranational Courts and the Dilemma of Migrant Vulnerability 134 (2019).

289 See Haddad, supra note 286, at 105; Strategic Litigation Impacts, supra note 282, at 61.

${ }^{290}$ Freek van der Vet, Transitional Justice in Chechnya: NGO Political Advocacy for Implementing Chechen Judgments of the European Court of Human Rights, 38 REV. CENT. \& E. EUR. L. 363, 376 (2013). 
regional networks that would facilitate the decision's implementation. This included partnering with the UNHCR office in Abidjan to help set up the Civil Society against Statelessness (CICA), a coalition of local NGOs with the mandate to act as a focal point for liaising with government actors as well as providing feedback and information to the Commission on the implementation of measures to combat statelessness. The OSJI itself also assisted these efforts by making submissions to the Commission outlining the steps that the Ivorian government had taken to implement the decision. ${ }^{291}$

Given the dearth of international and supranational jurisprudence on the conditions for the acquisition and denial of nationality, strategic litigation on statelessness can thus trigger medium- to long-term legal reforms, including in cases that result in losses, if litigators are able to incrementally move the courts' jurisprudence in a progressive direction or jumpstart domestic mobilization. ${ }^{292}$ In the same vein, instead of putting all their eggs in one litigation basket, strategic litigators on statelessness may adopt a more pragmatic "topographical" posture, whereby they simultaneously pursue remedies for tackling statelessness through different legal and political mechanisms at the domestic, regional, and international levels. ${ }^{293}$ The idea is that combining overlapping and mutually reinforcing liability regimes will not only prove to have a greater deterrent effect on states but also make it that much harder for them to introduce policies and measures that are designed to evade the precedential effect of a negative ruling in any particular legal regime. ${ }^{294}$ As cases such as the Dioula, those without nationality in the Netherlands, and the Kenyan Nubians demonstrate, strategic litigators on statelessness would be well advised to move beyond a court-centric focus and also consider initiating cases before "softer" mechanisms such as human rights treaty bodies. They should also explore the prospects of bringing nationality claims through international procedures that have seldom been tested. For example, it has been suggested that India's discriminatory citizenship laws discussed earlier could be challenged under the CERD Convention by a state initiating a complaint before the CERD Committee through the interstate mechanism. ${ }^{295}$

\section{Rethinking Legal Identity Documentation}

While formal legal actions are certainly one potential avenue to counter manufactured statelessness, no less important are policy and advocacy measures championed by international actors, in particular, those taken by the UNHCR as the nodal agency for tackling statelessness. In 2014, the UNHCR launched the \#IBelong Campaign with the ambitious aim to end statelessness in a decade. ${ }^{296}$ The campaign represents a major shift in the UNHCR's

291 Alpha Sesay \& Amon Dongo, Côte d'Ivoire's Statelessness Problem: Utilizing Multiple Tools to Support Implementation of Judgments, in Implementing Human Rights Decisions: Reflections, Successes, AND NeW DiRECTIONS 29 (2021).

292 See BAUMGÄRTEL, supra note 288, at 129 (arguing, in the context of migration, that even cases that are destined to fail may turn into "successes without victories").

${ }^{293}$ Nikolas Feith Tan \& Thomas Gameltoft-Hansen, A Topographical Approach to Accountability for Human Rights Violations in Migration Control, 21 GERMAN L.J. 335, 337 (2020) (outlining the contours of a topographical approach to strategic litigation).

$294 \mathrm{Id}$.

${ }^{295}$ See Priya Pillai, State Responsibility for Citizenship in India: Lessons from Myanmar, and the CERD Inter-State Communication Mechanism, OPINIO JURIS (Dec. 21, 2019), at http://opiniojuris.org/2019/12/21/state-responsibility-for-citizenship-in-india-lessons-from-myanmar-and-the-cerd-inter-state-communications-mechanism.

${ }^{296}$ Available at https://www.unhcr.org/ibelong. 
posture on statelessness on which it has historically been reluctant to adopt an interventionist stance for fear of compromising political support for its central activities concerning refugees and asylum seekers. ${ }^{297}$ To fulfill this mandate, the UNHCR has developed the Global Action Plan to End Statelessness: 2014-2024, which sets out ten actions that must be taken in order to end statelessness, including formal legal measures with respect to which it has already achieved some success, such as advocating for the removal of gender discrimination in laws governing nationality, improving data on statelessness, and encouraging accession to the Statelessness Conventions. Other prominent recommendations relate to ensuring birth registration and the issuance of nationality documentation to persons who would be entitled to it. $^{298}$

The UNHCR's emphasis on the acquisition of identity documentation to address statelessness has been echoed in the 2018 Global Compact on Refugees' program of action, which advocates civil and birth registration and documentation to reduce the risk of statelessness. ${ }^{299}$ It is also in line with the championing of legal identity and registration documentation by major international human rights and development agencies on the premise that they symbolize universal membership and confer a standardized equal identity on the bearer. ${ }^{300}$ This is exemplified in the language of the Sustainable Development Goals (SDG) setting out the target to "provide legal identity for all, including birth registration" by $2030 .{ }^{301}$ However, as this Article has argued, identification practices and documentation are a double-edged sword that can be used to both include and exclude. While the ascription of legal identity and its documentary proof can certainly enable access to essential goods and services such as health, education, housing, and finance, and promote the efficient functioning of social welfare programs, ${ }^{302}$ as scholars have noted, the very same document may carry different meanings depending on the political context and purposes for which it is employed. Identity documents "may be carried with pride, indifference, reluctance or even fear, depending on the political conditions and the history of using such documents in the country in question." ${ }^{303}$ Identity cards, in particular, have traditionally carried a range of negative connotations in countries where they have been used as a form of surveillance and control and to deny and restrict the rights of marginalized groups. ${ }^{304}$

As the examples in Part II have indicated, the drive to document and enumerate populations has at times had the paradoxical effect of rendering stateless individuals who fall out of the carefully constructed categories of citizens and "foreigners." Previous studies had

297 STAPLES, supra note 103, at 147.

${ }^{298}$ Other measures involve resolving existing situations of statelessness, granting protection to stateless migrants, preventing childhood statelessness and loss of nationality on discriminatory grounds and in cases of state succession. Global Action Plan to End Statelessness, supra note 7.

299 Global Compact on Refugees, $\$ 2.8$, UN Doc. A/73/12 (Part II) (Aug. 2, 2018).

300 See Samantha Balaton-Chrimes, Statelessness, Identity Cards and Citizenship as Status in the Case of the Nubians of Kenya, 18 Citizenship STUD. 15, 18, 20 (2014).

${ }^{301}$ UN General Assembly, Transforming Our World: The 2030 Agenda for Sustainable Development, Goal 16.9, UN Doc. A/RES/70/1 (Oct. 21, 2015).

302 See Bronwen Manby, The Sustainable Development Goals and "Legal Identity for All": "First, Do No Harm," 139 World Dev. 2, 3 (2021) (summarizing the economics and policy literature on the benefits of identity documentation).

303 David Lyon, Identifying Citizens: ID Cards as Surveillance 3 (2009).

304 See Rachel E. Rosenbloom, From the Outside Looking In: U.S. Passports in the Borderlands, in CITIZENSHIP IN Question, supra note 165, at 132, 140. 
examined the ways in which countries such as the Dominican Republic have implemented legal and non-legal measures to "forcibly displace" Dominican born persons of Haitian descent by forcibly attributing to them the putative nationality of their "native land" or risk being placed in a limbo state of statelessness. ${ }^{305}$ More recent scholarship has specifically highlighted the link between the identity documentation drive in the Dominican Republic and its impact on the exclusion of Dominicans of Haitian descent from citizenship. The push by international actors such as the UN, the World Bank, and the Inter-American Development Bank for the Dominican Republic to undertake population identification and civil registration measures in order to facilitate the delivery of social welfare programs had the paradoxical effect of unsettling the long established entitlements of Dominicans of Haitian descent. ${ }^{306}$ International actors such as the World Bank provided financial and technical support to implement registration policies at the macro-level but left the Dominican Republic free to determine the criteria for citizenship acquisition and eligibility for legal identity documentation. Thus, even Dominicans of Haitian descent who possessed the appropriate paperwork suddenly found themselves unable to renew their documentation or were faced with their confiscation. ${ }^{307}$

In the Kenyan case, the new digital identity system, "Huduma Namba," intended as a comprehensive registration system to guarantee legal identity and facilitate access and entitlement to government services and welfare programs, would theoretically have functioned as an inclusionary instrument that recognizes the status of marginalized communities such as the Nubians and Somali Kenyans as equal citizens. However, as advocates have argued, the Huduma Namba system is merely "layered over a history of exclusion" faced by these communities and replicates many of the endemic discriminatory practices in their access to identity documents. Not only may Kenyans from border communities, such as Somali Kenyans, be required to undergo vetting for community membership by local chiefs before being able to access the ID system, but the difficulties and delays in being able to prove this membership has driven some applicants to register as refugees simply to be able to gain access to services. ${ }^{308}$

Multiple domestic legal actions have been brought before Kenyan domestic courts, challenging, amongst other things, the broad discretion vested in registration authorities to demand additional forms of documentary proof of nationality from members of the marginalized groups as a violation of the right to equality and non-discrimination. However, in its January 2020 ruling, the Kenyan High Court held that the law establishing the digital identity system did not, on its face, establish any distinction between marginalized groups such as the Nubians and other Kenyans, and the evidence adduced before the court was insufficient to prove discrimination. Thus, while it recognized the possibility of the risk of exclusion of some groups and stressed the need for a regulatory mechanism to mitigate this risk, the court

305 See Kristy A. Belton, Rooted Displacement: The Paradox of Belonging Among Stateless People, 19 CitizENSHIP STUD. 907 (2016).

${ }^{306}$ HAYES DE KALAF, supra note 235.

307 Eve Hayes de Kalaf, Making Foreign: Legal Identity, Social Policy and the Contours of Belonging in the Contemporary Dominican Republic, in Welfare and Social Protection in Contemporary Latin America 101, 107 (Gibran Cruz-Martinez ed., 2019).

${ }^{308}$ Holly Ritson, "We Are Not Data Points": Highlights from our Conversation on the Kenyan Digital ID System, NYU Center for Human Rights and Global Justice (Nov. 9, 2020), at https://chrgj.org/2020/11/09/we-arenot-data-points-highlights-from-our-conversation-on-the-kenyan-digital-id-system. 
rejected the discrimination claim. ${ }^{309}$ Civil society actors such as the OSJI have nonetheless persisted in their advocacy efforts calling out the digital identity system as a form of indirect discrimination that violates the Kenyan constitution by penalizing marginalized groups who face difficulties accessing legal identity documentation required for registration. ${ }^{310}$

Scholarship analyzing the impact of identity documentation drives shows that far from being outliers, cases such as the Dominican Republic and Kenya are emblematic of the potential of new registration systems to reinforce discriminatory citizenship practices. The introduction of a new nationality identity card in Mauritania, for instance, has been claimed to be part of the government's strategy to revoke the citizenship of black Mauritanians and as a form of "biometric genocide." Similarly, concerns have been raised on the establishment of the Sudanese civil registration system and ID card as a tool to identify individuals of southern Sudanese descent and deny them the right to citizenship. ${ }^{311}$ These examples point to the depressing possibility that, instead of eliminating statelessness, the push by international actors to encourage or even require states to ascribe a legal status - and the accompanying identity document - to an individual, may inadvertently end up facilitating its entrenchment.

This does not imply that measures to access legal identity and documentation are automatically suspect; rather they suggest the need for agencies such as the UNHCR to recognize the Janus-faced nature of identity documentation as reinforcing the binary divisions between citizens and non-citizen others, at times to the detriment of those who the state wants to exclude from its imaginary. ${ }^{312}$ Instead of furthering the goal of "leaving no one behind," the promotion of legal identity documentation and registration without sufficient regard to the politics of documentation and evidence can end up reproducing marginalization and statelessness. International human rights and development actors should thus be cautious of an uncritical embrace of legal identity documentation and insist on advance and robust scrutiny of the legal framework and social context in which they will be implemented in order to prevent them from becoming tools of coercion and exclusion. ${ }^{313}$

\section{Conclusion}

The 1920s fictional protagonist of The Death Ship has much in common with the fleshand-blood stateless person today. Stripped of his nationality and legal identity in the territory he seeks to call home and unable to prove either his nationality or the lack of it, the stateless person inhabits an existential precariousness that knows no escape. As this Article has argued, international and regional courts and human rights bodies have been doggedly pursuing piecemeal efforts to challenge manufactured statelessness and, in the rare case, have done so with some success. However, even these progressive rulings have been characterized by

\footnotetext{
${ }^{309}$ Nubian Rights Forum \& 2 others v. Attorney General \& 6 others; Child Welfare Society \& 9 Others (Interested Parties) [2020] eKLR, at http://kenyalaw.org/caselaw/cases/view/189189.

${ }^{310}$ Open Society Justice Initiative, Litigation, Nubian Rights Forum et al. v. the Honourable Attorney General of Kenya et al. ("NIIMS Case"), at https://www.justiceinitiative.org/litigation/nubian-rights-forum-et-al-v-thehonourable-attorney-general-of-kenya-et-al-niims-case.

${ }^{311}$ Manby, supra note 302, at 7.

312 See Bronwen Manby, Naturalization in African States: Its Past and Potential Future, 25 CiTIZENSHIP STUD. 514, 525 (2021).

313 See Christoph Sperfeldt, Legal Identity in the Sustainable Development Agenda: Actors, Perspectives and Trends in an Emerging Field of Research, 26 INT'L J. Hum. RTs. 1, 14-16 (2021).
} 
adhocism and failed to ignite a "justice cascade" where states are routinely being called on to answer for the liminal no-man's land to which they have consigned thousands of people where none of the protections of citizenship apply. Moreover, as the cases of the Dominicans of Haitian descent and the Kenyan Nubians reveal, their actual impact on the reality of statelessness on the ground is questionable. States have either flouted the rulings, adopted an "à la carte" approach to implementing the least politically costly aspects of the rulings, surreptitiously backtracked on initial compliance measures, or found creative workarounds to avoid the international legal precedent.

In parallel, agencies such as the UNHCR have championed policy interventions to resolve statelessness by emphasizing the need for a state-centered response grounded in changes to nationality laws, documentation and registration practices, and improved data collection, to prevent and eliminate statelessness. However, some of these strategies that emphasize formal, technical reforms will do little to address the main pathways through which states manufacture statelessness in the shadow of the law. And others, such as identity documentation and registration drives may even prove to be counterproductive and exacerbate covert statelessness. Comprehensive identity management systems intended to serve as a "single source of truth," as claimed by Kenya's Huduma Namba — and often supported by technical and financial assistance measures by international human rights and development agencies—can be layered upon existing forms of exclusion or give rise to new ones.

This Article has argued that states' agility in countering halting efforts by international legal actors calls for an international legal roadmap that can go toe-to-toe with the various and evolving techniques the state implements to manufacture statelessness. This roadmap requires recognizing that rather than invite the wrath of international law by enacting overtly illegal or discriminatory rules and institutions, the state can instead achieve the same result by manipulating ostensibly egalitarian criteria for political membership such as time, territory, and administrative processes. Far from being neutral and unbiased, the effects of legal reconfigurations of time and space, and the requirements for empirical citizenship, are not randomly distributed but reflect pre-existing and extra-legal exclusions of certain types of people from the political imaginary of the nation-state. The ultimate result is thus often the same-statelessness that is caused by state-sponsored discrimination and inequalitybut implemented through facially neutral conceptual and policy instruments that fly under the radar of international law. This strategic statelessness is not evidence of the limits of the state's political authority, but rather constitutive of it: strategy that allows the state to exploit the vulnerability and labor of stateless persons, strategy that questions the loyalty of certain groups and paints them as unworthy of citizenship, and strategy that uses exclusion as a political weapon to facilitate people-building. ${ }^{314}$

For international legal actors to build and implement this roadmap, they would need to learn how to think and see like a state. To do otherwise would be to risk introducing a doctrinal or policy measure only to be outsmarted by the state carving out creative exceptions to its application. The Article has thus emphasized a multi-pronged approach that begins the process of constructing such a roadmap drawing on legal doctrine, litigation strategy, and policy. The first of these advocates developing the normative foundations and doctrinal contours

\footnotetext{
314 See Gibney, supra note 27, at 53-55 (on the various reasons motivating states to intentionally create statelessness).
} 
of international and regional legal norms on indirect discrimination. As various studies have shown, these have either been vastly underexplored or unevenly applied in the jurisprudence of regional human rights courts and the human rights treaty bodies. Since indirect discrimination is generally seen as avoiding the attribution of bad faith or an evil motive to the state, this may be a more palatable way for international bodies to signal the illegal impact of discriminatory state policies on statelessness.

Any doctrinal reform, however, can only be as good as the actors who use it to litigate statelessness. The Article has thus highlighted the potential of the "topographical" approach to strategic litigation on statelessness. This will involve international and local civil society actors exploring multiple legal fora-including those that may not be obvious choices for statelessness claims - to find different jurisdictional hooks to simultaneously pursue remedies for state manufactured statelessness. Spreading the litigation risk between different fora may also prevent any particular court being singled out as a repeat player and potentially being subject to backlash from disgruntled states.

And finally, the Article has recommended revisiting the policy push by agencies such as the UNHCR for legal identity documentation and registration as an instrument to tackle statelessness. As the various examples ranging from the UAE, India, Kenya, the Dominican Republic, and other parts of the world undergoing rapid upgrades in identification and registration systems have shown, without advance assessment of the legal framework and political conditions in which these systems will be implemented, they can easily mutate into technologies of exclusion rather than inclusion.

Vital as these reforms are, they make no claim to be a panacea for all the ingenious ways in which states may potentially manipulate facially neutral criteria of time, space, and documentation to produce statelessness. In this sense, they are not directed at achieving the international community's aspirational goal of ending statelessness in a decade. Rather, they are intended to narrow, as much as possible, and within the existing limits of the international legal order, the circumstances in which states can discriminate against and exclude those who have a prima facie sufficiently close connection with the state to be able to claim citizenship in order to engineer and maintain statelessness. The ambition of these proposals is thus- to take a page out of the European Court of Human Rights' playbook - one of ethical incrementalism rather than radical overhaul. The hope, nonetheless, is that this decision to "hasten slowly" inspires more revolutionary counter-narratives on statelessness. These may involve rethinking the nature of citizenship as a politico-legal institution that is associated with a certain set of rights, territory, and form of political authority. And to refashioning principles of citizenship allocation in a global political and legal order that systematically produces vast inequalities in the distribution of political power and resources. 